Portland State University

PDXScholar

\title{
Worker perceptions of the fast-food giant : interviews with and class comparisons of teenagers working at McDonalds
}

Joyce A. Korshgen

Portland State University

Follow this and additional works at: https://pdxscholar.library.pdx.edu/open_access_etds

Part of the Psychology Commons, and the Work, Economy and Organizations Commons Let us know how access to this document benefits you.

\section{Recommended Citation}

Korshgen, Joyce A., "Worker perceptions of the fast-food giant : interviews with and class comparisons of teenagers working at McDonalds" (1987). Dissertations and Theses. Paper 3716.

https://doi.org/10.15760/etd.5600

This Thesis is brought to you for free and open access. It has been accepted for inclusion in Dissertations and Theses by an authorized administrator of PDXScholar. Please contact us if we can make this document more accessible: pdxscholar@pdx.edu. 
AN ABSTRACT OF THE THESIS OF JOYce A. Korschgen for the Master of Science in Psychology presented July 22, 1987.

Title: Worker Perceptions of the Fast-Food Giant: Interviews with and Class Comparisons of Teenagers Working at McDonald's.

APPROVED BY MEMBERS OF THE THESIS/COMMITTEE:

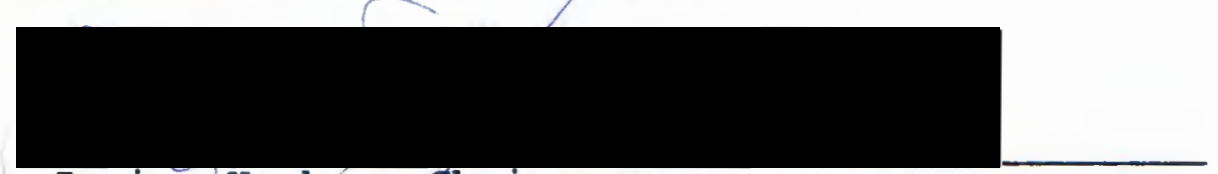
Janice Haaken, Chairperson

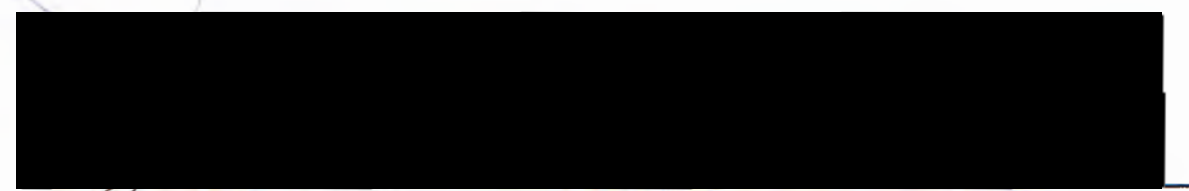

Jobanna Brenner

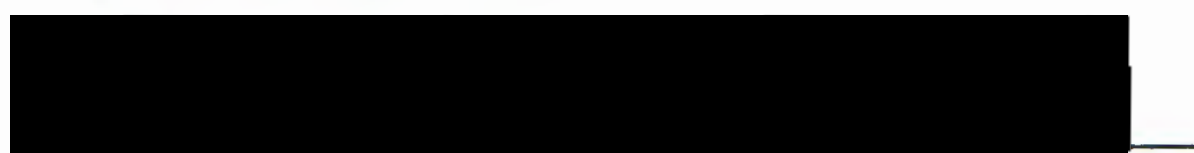

cathieen smith

This study examines the relationship between social class and adolescents conceptions of work. Four major areas of the adolescent's work experience are examined: (1) tasks and training, (2) relations with co-workers and managers, (3) organizational structure and change, and (4) family life and work. Forty female adolescent, nonmanagerial employees who worked part time at McDonald's 
franchise stores were interviewed. Two groups were formed: one middle class group $(n=2 \varnothing)$, and another working class group $(n=20)$. An item by item content analysis was performed on data tested for rater reliability. No significant results were found with regard to relations with co-workers. However, significant results were found in all four areas. These include: (1) middle class respondents were more likely than working class respondents to adopt a technical approach to training, (2) middle class respondents were more apt than working class respondents to seek positive, affective ties with managers, (3) middle class respondents were more likely than working class respondents to identify efficiency as a rationale for McDonald's organizational structure, (4) middle class respondents were more likely than working class respondents to deal with perceived unfairness by talking directly with management, and (5) working class respondents were more likely than middle class respondents to identify the principle of the necessity of work as the lesson in their family work experience most helpful in adjusting to service work, whereas middle class adolescents identified abstract capabilities as the most helpful lesson in their family work experience.

In addition, in using motivation for employment and age yas exploratory predictors, three significant results appear. First, respondents working for basic needs were 
more likely than those working for extra money to identify unfairness at work in the form of exploitation. Secondly, respondents working for basic needs were more likely than those working for extras to identify endurance as a means of dealing with unfairness. Finally, adolescents 17 years and older were more likely than 15 and 16 year olds to report some knowledge of workplace mobility. 
WORKER PERCEPTIONS OF THE FAST-FOOD GIANT: INTERVIEWS WITH AND CLASS COMPARISONS OF TEENAGERS WORKING AT MCDONALDS

by

Joyce A. Korschgen

A thesis submitted in partial fulfillment of the requirements for the degree of

MASTER OF SCIENCE

in

PSYCHOLOGY

Portland State University 
TO THE OFFICE OF GRADUATE STUDIES AND RESEARCH:

The members of the Committee approve the thesis of

Joyce A. Korschgen presented July 22, 1987.

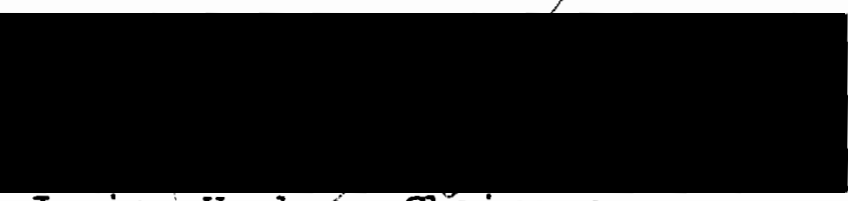

Janice Haaken, Chairperson

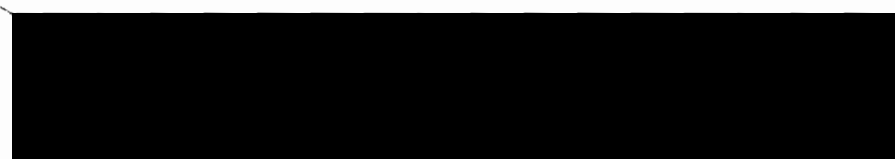

Johanna Brenner

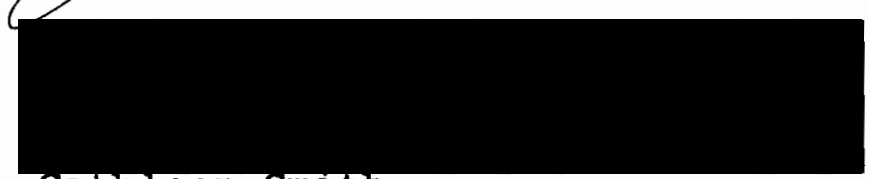

cathleen smith

APP ROVED :

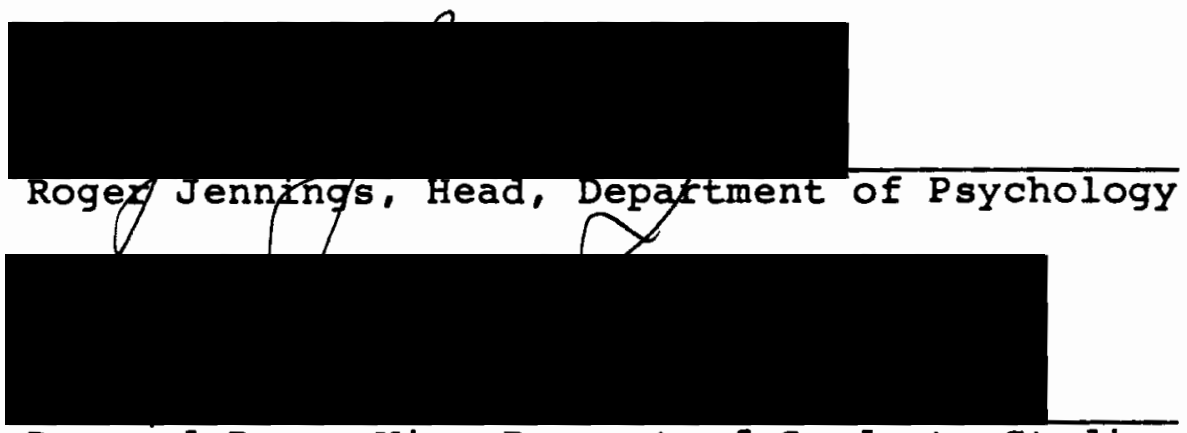

Bernard Ross, Vice Provost of Graduate Studies 


\section{ACKNOWLEDGEMENTS}

I wish to thank all who contributed to the completion of this research. First, I extend my sincere appreciation to my chairperson, Dr. Janice Haaken for her collaborative assistance in this project. For their continued support of this project, I wish to thank my family members. A special appreciation to my partner, Barbara Wilkins, for her patience, support and scholarly critique of this project. 
TABLE OF CONTENTS

PAGE

ACKNOWLEDGEMENTS....................... ii

LIST OF TABLES......................... vi

LIST OF FIGURES........................ vii

CHAPTER

INTRODUCTION....................... 1

I REVIEW OF THE LITERATURE............ 6

The Advent of Adolescence as a

Developmental Phase............... 7

Teenage Employment as Socialization to

Adulthood...................... 11

Adolescence Social Cognitive

Development...................... 17

Social Class and Social Cognition...... 21

Adolescent Employment \& Family Life..... 27

II METHOD........................ 34

Participants.................. 34

Procedure..................... 36

RESULTS........................

Tasks \& Training................ 57 
Social Relations with Co-Workers and

Management.................. 58

Organizational Structure and Change..... $6 \varnothing$

Family Life and work.............. 65

III $\quad$ DISCUSSION ...................... 68

Tasks and Training................ 71

Social Relations with Management and

Co-workers...................... 72

Organizational structure and Change..... 74

Family Life and Work............. 82

CONCLUSIONS.................... 84

REFERENCES............................. 89

APPENDICES

A. INITIAI RESEARCH QUestions............ 95

B. CONSENT FORM.................... 96

C. CATEGORY DEFINITIONS OF RESPONSES WITH MINIMAL VARIANCE............... 97

D. RESULTS OF RELIABILITY STUDY........... 104 


\section{LIST OF TABLES}

TABLE

PAGE

I. Interview Questions...................... 41

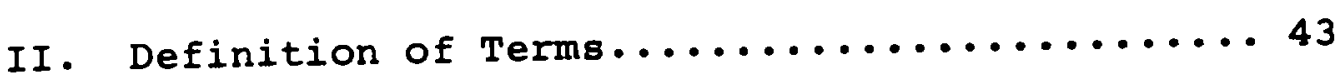

III. statistical sumary...................66 
LIST OF FIGURES

FIGURE

PAGE

1. Findings Related to Social Class....... 7ø

2. Findings Related to Motivation for Employment..................... 71 


\section{INTRODUCTION}

The steady increase in teenage employment in recent decades has generated considerable controversy about its effects on adolescents' psychosocial development. Early research on adolescence and work was largely confined to the effects of paid work experience on the acquisition of adult attitudes and behaviors (Behn, et al., 1974; Bucknam, 1976; Elder, 1974), school performance (Bateman, 1950;

Straus \& Holmberg, 1968) and later work aspirations (Behn, et. al., 1974). Adolescent work was also seen as a factor decreasing delinquency (cloward and Ohlin, 1960; Hirschi, 1969). While some research suggests that paid work may be detrimental to development, e.g., increasing drug abuse or delinquency (Greenberger, Steinberg, and Vaux, 1981; Shannon, 1982), the assumption behind much of this empirical research has been that experience in the "real world" of adult work is essentially beneficial to adolescents, offering an antidote to the seeming irrelevance and infantalizing effects of secondary schooling. Experiences which hastened the transition to adulthood were viewed as consonant with the major developmental tasks of adolescence. Other developmental literature has suggested a more cautious and protective tone, endorsing some aspects of teenage employment while 
emphasizing the dangers of subjecting young people to low-paid, menial, stressful jobs. The concern is that the conditions under which adolescents typically work threaten to overtax their fledgling adult capacities (Hamilton and Crouter, 1980; Steinberg, 1982a).

The study presented here grows out of recent debates on adolescence and work, where developmental researchers have taken this more cautious, critical stance and have attempted to separate out beneficial and problematic or destructive effects of early work experience. While this recent developmental focus has raised questions about social cognitive processes associated with early work experience (Greenberger, E., Steinberg, L., Vaux, A., and McAuliffe, S., 1980), there has been very little effort to pursue empirically these processes, i.e., how adolescents conceptualize social relations in the workplace.

This study focuses primarily on social class as a determinant of how adolescent part-time workers conceptualize social relations in the workplace. Specifically, I am interested in how class background influences choice of work and adaptations to work settings, conceptions of managerial authority, cooperation with co-workers, conceptions of means of change, and the relationship of family work to paid experiences. 
The study focuses on female fast-food workers at McDonald's for several reasons. First, McDonald's is the largest single employer of teenage fast-food service workers, particularly female adolescents, in the U.S. (Luxumberg, 1985). Second, McDonald's stores are located both in suburban settings (providing greater likelihood of drawing workers from middle class neighborhoods) and in the inner city (providing a greater likelihood of drawing workers from working class neighborhoods). Third, McDonald's has been hailed as a "model" for the service industries as evidenced by ability to remain competitive by standardizing and routinizing the production of food services (Roddock, 1982).

McDonald's emphasis on standardized managerial and production processes across franchise stores has important methodological and social implications. Methodologically, it provides an alternative to much of the existing research which is based upon combining different kinds of work settings. The choice of settings is intended to control for variation in type of work and work conditions, hence the adolescents in this study perform essentially the same type of work under essentially the same conditions. Socially, this highly routinized approach to service work represents an important and increasing phenomenon with particularly problematic implications for women and girls who are concentrated in service sector employment (Hochschild, 1983). While researchers in the area of 
adolescent employment stress the limited learning possibilities associated with this kind of work, it was my starting assumption that adolescents learn a great deal in such settings about how these fast-food capitalist enterprises operate, both technically and socially. This study aimed to determine what, specifically, female adolescents did learn and how class background influenced this learning.

My interest in pursuing questions about adolescents in service work has been heightened by the rapid growth of the service industry worldwide in the past several decades. McDonald's corporation, in particular, has sustained a growth rate which easily claimed worldwide notoriety when in 1984 McDonald's became a larger employer than U.S. Steel (Bluestone, et. al., 1985). Fast food restaurants are the most rapidly growing segment of service industry, with hamburger restaurants accounting for 508 of all fast food restaurant sales, or $\$ 18$ billion worth of business. Burger King, with about $\$ 2.5$ billion in sales, is second only to McDonald's which boasts a phenomenal $\$ 8.7$ billion in 1983 revenues, up 11.58 from 1982. Indeed, McDonald's is the established fast food giant, cornering 408 to 458 of the market over 4 years (Kindel, 1984). Within the last three decades, steadily rising fast food sales indexed have been documented. McDonald's, the consensual leader in fast food, in 27 years has expanded into a multimillion dollar industry. McDonald's Corporation licenses and operates 
9,182 self-service restaurants throughout the U.S., Canada, and overseas employing 136,000 people. Profits have risen to $\$ 490$ million in 1986; a 258 gain over a 2 year period. Value Line estimates are for a 560 million dollar profit in 1987 (Value Line, Jan. 2, 1987, p. 324). With the built-in need for employees who can work part-time during the midday rush, fast food restaurants have relied chiefly on the labor of young people (Ginzberg, 1977).

Chapter I reviews literature pertaining to the study. Initially, I focus the review on academic influences on the formation of the conceptualization adolescence as a developmental phase, and the employment and socialization literature. I then review three social-psychological literatures: social cognition and development; social class and social cognition; and adolescent employment and family life. The literature review outlines themes addressing the impact of work on adolescent acquisition of adult values, skills, and orientations to work life. Within this context I raise questions about the workrelated development of self-direction vs. conformity, the importance of qualitative research to the exploration of the process and meaning of work relationships for adolescents, and the importance of social class in the development of an interpretive framework from which adolescents view the work they perform. 


\section{CHAPTER I}

REVIEW OF THE LITERATURE

In the following section I examine interdisciplinary literatures which came in response to the recognition of adolescence as a distinct developmental period and I review psychological literature related to adolescence and employment. In exploring the historical context of adolescence I go beyond the existing literature by providing a context for evaluating the experience of adolescence as it exists today. While existing studies explore the developmental impact of highly routinized and fast-paced work (Steinberg, L., Greenberger, E.,Vaux, A., \& Ruggiero, M., 1981; Steinberg, 1982a), researchers often take as a given the nature and structure of routine work.

I focus on sociological factors influencing the developmental impact of routine service work in order to provide a context for explaining adolescents' conceptions of work processes. In providing this context, I extend the existing literature on adolescent employment and social cognition which stops short of an analysis of the work setting. For example, steinberg and Greenberger (1981a) conclude, on the basis of survey data, that working adolescents are more cynical about work and are more likely 
to endorse "unethical business practices" than are nonworking adolescents. However, the authors do not attempt to explain what it is about work that contributes to these attitudes nor do they attempt to distinguish between cynicism and critical thinking in relation to work. The later distinction is important. Cynicism implies a certain resignation or acceptance of antisocial behavior whereas critical thinking suggests a broader range of attitudinal and action possibilities.

The Advent of Adolescence as a Developmental Phase

Adolescence as a developmental phase and the impact of work on the developing adolescent have been the focus of a number of historical studies. In an article on the history of adolescence, Demos and Demos (1969) critiqued the notion of adolescence as a universal developmental stage. They describe "adolescence" not as a fact but rather as an idea or conceptualization which became well established in the public consciousness in the early part of the 20 th century. Drawing on a growing 19 th and 20 th century literature of child-rearing advice, and a large body of books and pamphlets directed to the young people of the country, these authors compare literature before 1825 to the industrial period which followed and identify changes in child rearing practices which parallel shifting literary trend. 
Before about 1825, Demos and Demos (1969) report that books were "mild in tone and full of simple moral homilies strung endlessly together." They were not directed to any particularly problematic or pressing needs in the lives of their readers. After 1825, Americans witnessed a period marked by intense nationalism, an interest in childhood as distinct from adult experience, and general anxiety about the quality of family life (Wishy, 1969, p. 86). During this period not only did the U.S. experience a rapid rise in the production of child-rearing books, some of which sold many thousands of copies, but the books imparted a qualitatively different message. Most of the concern related to problems of parental authority. The role of parents as disciplinarians needed to be established early in the child's life and firmly maintained throughout the years of growth. Even infantile "wilfullness" that "springs from a deprived nature and is intensely selfish" was to be suppressed by strict training in obedience lest it gain momentum and strength resulting in dire implications for the later adult personality (Bulkeley, 1858, p. 12). Toward the end of the 19th century, some writers began to publicize discussion of the moral "dangers" and "temptations" threatening youth directly from urban life. Inner-city influences such as "the varied population," "the chaotic social and economic life," "the frenzied commercial spirit," and "dazzling entertainments" 
were in direct opposition to proper growth into adulthood (Hepworth, 1870).

In academia, during the late 19 th century $G$. Stanley Hall and his associates were, for the first time, advancing the concept of adolescence to the public. His "child study" movement aimed toward a deeper public and scientific understanding of human development. Profoundly influenced by Darwinism, Hall's theory of adolescence was explicitly linked to an evolutionary, or "genetic" model. In likening adolescence to a "recapitulated" period of rapid evolutionary growth, Hall elaborated the idea of "storm and stress," or severe crisis characterized by "lack of emotional steadiness, violent impulses, unreasonable conduct, lack of enthusiasm and sympathy..." (Hall, 1882, p. 30$)$.

Hall's influence was indeed reflected in a flourishing of texts in psychology, education, child-rearing, and child labor. Many of his ideas were not entirely innovative but they did produce a reshaping of certain popular beliefs about youth at the time. Still, many questions about the new concept of adolescence remain. In particular, the salience of his ideas may reflect larger developments in American society such as the transformation of the United States from an agricultural into an urban and industrial society. This historic period, 18th and 19 th centuries, is in fact particularly important in that it marked a dramatic change in the material basis of family life ushered in by 
the rapid expansion of industrial capitalism. The protective quality of parental authority was, to a large degree, undermined by the repressive authority of the industrial capitalist. Youth in some cases found themselves competing with their parents for wage work (Ewen, 1976, p. 14ø). The "storm and stress" of adolescence characteristic of Hall's conceptualization may be a reflection of a growing discomfort with changes in work-family relations brought on by the advent of modern industrialism.

Ewen (1976), in his examination of the role of youth as an ideal suitable to the needs of industrial capitalism, asserts that management projects an expectation of youth. Viewed as highly impressionable and hedonistic, young people represent willfullness and are a symbol of endurance. Ewen asserts that this made youth a usable tool in the ideological framework of business (p. 139). Ewen contends that youth was and is a symbol of the kind of control routinized work imposes upon young people. Training and skill, which had been the basis of the apprentice-master-craftsman system was, over a period of a few years, displaced to the speed and endurance required of mechanized production. Likewise, authority previously afforded the skilled elders in the the workplace was now shifted to the quicker, more efficient younger worker ( $p$. $14 \varnothing)$. 
Teenage Employment as Socialization to Adulthood

Modern sociological research on the impact of work on adolescent development is still in the early stages of development and is thus quite limited. However, Elder's (1974) research on children of the Depression Years is often cited as evidence for the positive impact of adolescent work experience. A consequence of this period's economic instability was reflected in what Elder calls the "downward extension of adultlike experience" for adolescents who took paying jobs outside the home. Boys in the study who worked showed a much greater interest in adults and spent more time with them in school-related activities than other children. Elder suggests that the economic hardship and some nonspecific aspects of work outside the home increased working boys' desire to associate with adults, to "grow up" and become adults. Other correlates of working for boys include the responsible use of money, energetic or industrious behavior, and social independence (pp. 81-82). Critics of this longitudinal study express serious hesitation in applying these findings to contemporary teenagers. Comparisons between contemporary and past cohorts are constrained by many specific historical factors. For example, young people during the 1930's were more likely than are adolescent's today to make essential economic 
contributions to their families' well-being (Hamilton and Crouter, 1980).

Social psychological theory and research on teenage employment is also sparse. As an area in the nascent stage of development, research has been largely confined to the effect of part or full time employment on the acquisition of adult attitudes and behavior (Elder, 1974; Bucknam, 1976), Behn, et al., 1974) and the effect of work on school performance (Bateman, 1950, Straus and Holmberg, 1968; Steinberg, Greenberger, Garduque, and McAuliffe, 1982b; Steinberg, Greenberger, Garduque, Ruggiero, and Vaux, 1982c). Recent literature addressing the issue of the adolescent work experience is attempting to focus on the specific developmental needs of youth. A number of researchers and theorists have argued that personality characteristics such as autonomy, self-esteem, responsibility, purposefulness, self-reliance (Steinberg et al., 1981a) and enhanced social understanding (Steinberg, Greenberger, Jacobi, \& Garduque, 1981b) are facilitated by paid work experiences.

Greenberger, et al., (1981) suggest that work experience may adversely affect the developmental process of adolescence. In addressing the consequences of job stress, they list three reasons why work experience may affect adolescent well-being adversely. First, significant hours of work may strain the already overloaded adaptational resources of an adolescent who is involved in 
school, adjusting to changing family roles and rules, and exposed to increasing peer pressures. Second, the nature of much of the work youngsters do may be incompatible with the developmental needs of the teen years. Adolescents who are confronting issues such as the development of autonomy and responsibility may find themselves facing everyday jobs which appear trivial or afford few opportunities for self-direction. Youngsters who are struggling with social acceptance and their impending separation from nurturing adults may be severely stressed by a job setting characterized by autocratic supervision and repressive authority. Three, in addition to the emotional stirrings of adult role expectations, adolescence is a time of dramatic developmental shifts, changes in appearance, and cognitive competences (Stevens-Long \& Cobb, pp. 198, 133). If these physical and emotional stresses are accompanied by additional stressful events such as death of a loved one, adolescents may be at even greater risk for job related health consequences of stress than adults.

Greenberger et al., (1981) describe a number of working conditions which are potentially stressful. These include poor work environment (time pressure, limited worker control over the pace of work); meaningless tasks, (boring or repetitive work); conflict with other roles, (work which interferes with school or home life); autocratic supervision, (the worker is told what to do and feels no freedom to disagree with supervisor); impersonal 
organization, (worker does not feel attached to supervisor or work peers); low wage structure, (worker is paid below minimum wage or feels wage is too low). Results of the Greenberger et al., (1981) study indicate that worker status is predictive of somatic symptoms and school absence, with workers reporting more school absences but fewer somatic symptoms than non-workers. Among workers, there was a positive correlation between time spent in the workplace and the use of cigarettes, alcohol, and drugs.

In addition to discussing the relationship between working adolescents and the developmental process, Greenberger, et al., (1981) conclude that there are gender specific effects of work. They found that an impersonal work environment was positively associated with stress for girls and that an autocratic form of supervision was positively associated with stress in boys.

The Greenberger, et al., (1981) research draws attention to one of the important flaws in contemporary research in this area. As I indicated at the beginning of this chapter, the quantitative research methods so often used in work settings are of limited value when the process and meaning of work are the focus of the investigation. Greenberger, et al.. (1981) rely on the use of questionnaires in gathering all of the data for their study. A limitation of this kind of data is that a more detailed analysis of how work experiences are conceptualized is not possible. While the finding that 
teenage workers tend to have increased use of cigarettes, alcohol, and drugs is important, it is not clear whether they perceive this as a means of coping with stressful work. There are also a range of ways of coping with stressful working conditions which have not as yet been examined.

Some contemporary research on the developmental outcome of work focuses on the effect of work on school performance or future career options. Experience Based Career Education (EBCE), sponsored by the National Institute of Education as an experiential education program, was implemented in many school systems in 1975. This study has been used, until recently, as a chief source of information concerning the long range benefits of adolescent work experience. As Hamilton and Crouter (1980) state, these studies provide poor evidence for the assertion that knowledge of career options during adolescence significantly affects adult work history. Further, evidence that experience is the best source of career knowledge has not been demonstrated (p. 329). In fact, drawing on hypotheses about the nature of most adolescent experience of the workplace, the conclusion that youngsters would prepare themselves for managerial jobs through higher education as a result of their exposure to managerial type careers may be inaccurate. What seems more clear is the notion that young people would prefer to avoid the low-paying dead-end jobs they have been exposed to and 
thus concentrate their academic efforts in the direction of higher paying-managerial type jobs.

Defenders of the program, however, can point to documented beneficial effects. Evaluations of the EBCE program by regional laboratories and by the Educational Testing Service (ETS) showed that the program was accepted. General popularity of the program among students, parents, and employers was reported. No academic losses were found when EBCE students were compared with non-EBCE controls and some differences were found in favor of the EBCE group in knowledge of and attitudes toward careers (Bucknam, 1976). Without data confirming the effect of the EBCE experience on future job success, i.e. finding and holding a job, or whether the students" behavior in other settings was affected, critics of this study cite the lack of data about specific developmental effects of work (Watkins and Corder, 1977 cited in Hamilton and Crouter, 1980). The ETS finding that EBCE students were "more concise and able to speak easily with an adult interviewer than non-EBCE students," is, however, consistent with Elder's finding that employed youth were more "adult oriented" than other youth.

An avenue of recent work in teen employment has found a focus on the impact of employment on school performance. Early systematic study in this area used standardized measures of academic achievement (Bateman, 1950; Straus and Holmberg, 1968). More recently, clear evidence has 
surfaced which is unsupportive of the notion that work experience has any positive effect on school performance. On the contrary, steinberg $(1982 c)$ reports that teenagers working more than 15 to $2 \varnothing$ hours per week during the school year earn lower grades as a result of the work cutting into the adolescent's school hours, family involvement, and peer activities. By way of elaboration, these authors suggest that, in those youngsters adversely effected, early work experience may occur before the need for school, peer, and family socialization processes has been fulfilled.

There have been attempts at addressing the importance of family life and the importance of assessing the impact of an interpretive framework in adolescent's experience of work. Some authors, for example, cite the lack of careful research attending to differences among teenagers in relation to their experience of work settings and the alienating conditions of work in general (Behn, et al., 1974; Keniston, 1971). Moreover, the acquisition of adult-like and adult-oriented characteristics, as shown by Elder (1974) and others, is not necessarily a positive outcome of work experience and should not be accepted uncritically.

Adolescence and Social Cognitive Development

One aim of this study, as stated earlier, is to explore the working adolescents' capacity for 
social-cognitive learning through work. The growth of social cognition in adolescence - the ability to think about social processes and social institutions - is directly related to the adolescent's growing capacity for abstract reasoning. This capacity to think on different levels, to make inferences about processes which underlie concrete, observable behavior, and to conceive of alternative possibilities in social situations, provides much of the basis for the adolescent's heightened capacity for social cognition.

The workplace is becoming an increasingly important arena of social cognitive learning for adolescents. Whereas in 1940, only 58 of male and 28 of female high school students worked during the school year, by $1980,2 / 3$ of high school seniors and $1 / 2$ of high school sophomores worked part-time (Steinberg, 1985). While there are problematic consequences associated with part-time work, the most important developmental benefit to adolescents of this increased labor force participation is greater interpersonal competence and "general social cognitive abilities" (Steinberg, et al., 1981a). By entering a new social setting, one requiring cooperation with others and some understanding of organizational processes, the adolescent experiences the increased dissonance which may be conducive to some kinds of new learning.

But again, illustrating the limitations of this kind of research, the literature tells us little about what 
those "general cognitive abilities" are - what adolescents learn, specifically, about authority, cooperation, self-control and the overall social organization of work as a function of direct work experience. The scant research on social cognition and adolescent employment is based primarily on questionnaire data which tell us virtually nothing about the cognitive processes and sources of conflict experienced by the working adolescent. The most direct effort to probe the social cognitive dimension of adolescent work experience was carried out by Steinberg, et al., (1981a). As a follow up to their questionnaire study, they interviewed 100 working teenagers. They identified three themes in the interviews which corresponded to their theoretical interests in social cognitive learning. They were specifically interested in examples which illustrated social sensitivity (empathy, perspective-taking), social insight (the ability to reflect on the meaning of interpersonal institutions and processes), and social communication (the ability to intentionally manipulate others in achieving some goal). The authors found evidence of all three types of social cognitive processes in the interview material. However, it is not clear that there was an extensive and systematic effort to identify thematic trends in the interview material. Another problem is in the theoretical and conceptual themes used to illustrate interview material. One example of a gratuitous leap from theory to 
anecdotal material is what the authors offer as an example of "a more sophisticated understanding of the nature and dynamics of the relationships between workers and supervisors, and among co-workers." They illustrate "sensitivity to an organizational superior" with the following comments by adolescent workers:

Well, they (kids) get used to being bossed around. You know, some people they don't know how to be bossed around.

I get along (with my boss), sometimes... I get kinda mad... I can't do nothing because he's my boss so I can't say nothing...(p. 149).

The implication here is that the mere exercise of self-control represents a "sophisticated understanding" of and sensitivity to authority. The main thesis is that such experiences represent a valuable "antidote to egocentrism" (Steinberg, et al., 1981a). But many of the anecdotes described could be as easily interpreted as injurious to self esteem or as simply adaptation to oppressive experiences. No criteria are provided for making distinctions between healthy and destructive experiences with authority figures.

While most of Greenberger and Steinberg's (1980) research focuses on the effects of working on other major settings in the adolescent's life, they do present some additional findings related to social relations and work. In comparing relations at work with relations with family and non-work peers, they found that workers reported feeling less close to their supervisors and co-workers than 
to significant others (Greenberger, et al., 1980). The finding concerning supervisors was puzzling, however: the only person who was described as less close than supervisors was their favorite teacher at school (p. 198). This suggests that the criteria for measuring closeness, e.g., willingness to discuss personal problems, may not have exhausted the important dimensions of closeness. For example, the tendency toward idealization and identification, i.e., to create exaggerated estimates of one's own potential vis a vis others and to associate one self closely with a group or cause, represent forms of psychological closeness which do not necessarily correspond to readiness for self-disclosure (Horney, 1966). Willingness to discuss personal problems is a particularly problematic criterion in the workplace where fear of retaliation by supervisors may inhibit self-disclosure. At the exploratory level, a primary aim of this study was to identify some of these important dimensions of workplace relations.

Social Class and Social Cognition

This study focuses on social class as an important determinant of an adolescent's interpretive framework in the work setting. As children move from early to late childhood, class background becomes increasingly important in shaping their self-conceptions (Rosenberg and Perlin, 
1978; Demo and Savin-Williams, 1983) and conceptions of what is required normatively in the world of work (Hochschild, 1983). I would expect that social cognitive learning for working adolescents is influenced by the social class of their parents. I am particularly interested in class differences in conceptions of and identifications with managers, and conceptions of and cooperative alliances with co-workers. In the following section I review of literature on social class which explores the importance of social class in the adolescent's workplace.

One of the problems that emerges while building on the existing literature on social class is that there is no general agreement on what terms such as class, middle class, and working class mean (see White, 1980). There are, however, two general ways of conceptualizing social class in social science research. One approach, which is essentially quantitative and structural, views class as equivalent to different strata of society as measured by a set of indices, e.g., income, education, prestige and occupational status. These groupings or strata are not conceptualized in terms of the interdependence or conflicts which characterize the relationship between social classes in a given society. The other main approach, derived from Marxist theory--and which guides this analysis--treats class as a social relation, specifically as social relations derived from the production process. Class 
refers to 1) a common position relative to the means of production, i.e., ownership or extent of control over the production process; whether one is in the position of buying or selling labor power, 2) an interest different from and in conflict with at least one other class because of these differing relationships to the production process and 3 ) different cultural and social practices (Oppenheimer, 1985, p. 12).

But what are the social psychological implications of these structural considerations? Kohn's (1977) extensive research on social class and psychological functioning provides the findings most relevant to my research interests, particularly in making the link between upbringing and the development of different social cognitive capacities. Kohn's criteria for making social class comparisons are similar to mine: he argues that working conditions, particularly extent of control over work, is the most important dimension of class in predicting psychological outcomes (Kohn, 1977, p. xlvi). Criteria in this study overlap considerably with Kohn's but include control over other people as an important dimension of social class.

Kohn (1977) concludes that values acquired through work differ according to social class and that these same values are often transmitted to offspring. The differing working conditions associated with working class and middle class jobs - most importantly, the possibilities for 
decision-making, freedom from close supervision, and intellectual complexity create different understandings of what is required normatively in the work world. These experiences influence, in turn, the lessons parents pass on to their children.

Kohn's writing attempts to explain class differences in the workplace through an examination of rules of discipline in family life. The most important values related to class position and work are self-direction and conformity to external authority. Kohn (1977) found that individuals who had higher level jobs were more likely to value self-direction and that those with lower level jobs were more likely to value conformity to authority. At the same time, Kohn challenges the notion that working class parents induce conformity by punishing their children more than do middle class parents. What differs, according to social class, is not the frequency but the form of punishment. Working class parents are more likely to punish according to the consequences of behavior, e.g., when the child's behavior reaches a certain threshold of tolerance, whereas middle-class parents are more likely to punish on the basis of inferred motivation or intentions, e.g., whether or not the child "intended" to be destructive (Kohn, 1977, p. 104). This difference is believed to account for the greater capacity of middle class individuals, apparently beginning with adolescence, to think in more "psychological" terms about social processes 
and to value self-direction and autonomy over conformity to authority (steinberg, 1985). It is also believed to account for a greater tendency among middle class children to be attuned to the feelings of authority figures because compliance is more apt to be achieved by appealing to feelings (Bernstein, 1974).

Kohn's (1977) research raises questions that I feel are as yet unanswered and as such are included among the aims of my study. Specifically, the relationship between social class and conformity to authority seems far more complex and contradictory than Kohn's analysis suggests. For example, Kohn's findings don't explain why the greatest support for Joseph McCarthy during the 1950s came from among upper-class and upper middle class voters (Hamilton, 1972). Although working class people tend toward less tolerant responses on attitude surveys, they also tend to support more liberal candidates. The history of trade unionism also provides strong evidence that resistance to authority is more apt to come out of the working class than the middle class (Oppenheimer, 1985, p. 184).

In addition, it is important to recognize that the same behaviors can be simultaneously acts of conformity and rebellion. For example, group pressure to conform to production rates (taboos against "rate busting") represent a form of group solidarity in resisting managerial control (Edwards, 1974). In this situation, group conformity (or, more positively, group cooperation) has the aim of 
achieving self-direction and resistance to authority. So too, the middle class person's competitive strivings may appear to be self-directed behavior but may be motivated by those internal representations of authority figures whose love and approval are sought. What is key in these examples is the $\operatorname{aim}(s)$ of the behavior and the importance and position of relationships, i.e., the relational configuration in which the behavior is embedded.

The question of the importance of the workers' socioeconomic class (SEC) in relation to job stress is not often addressed in social-psychological research. The notable exception is the study by Greenberger, Steinberg, \& Vaux (1981). Using father's occupation an an index of socioeconomic class, results show that SEC significantly predicts (a) psychological distress among males, with middle class boys reporting fewer symptoms; and (b) cigarette use among females, with girls from working class families reporting higher use. Work status, however, is predictive of somatic symptoms and school absences, with workers reporting more school absence but fewer somatic symptoms than non-workers in all classes (p. 696).

Results of epidemiological studies also provide support for the finding that low job status is psychologically stressful. Findings indicate that individuals of "lower" socioeconomic status, and thus lower job status, were more likely than higher status workers to exhibit psychiatric symptoms and to be hospitalized and 
rehospitalized (Dohrenwend \& Dohrenwend, 1974).

Greenberger, et al., (1981) argue the possibility that even without considering the job status factor, stressful

situations have a high prevalence in "lower" class environments. The authors do suggest, however, that the issue of job status is not incidental among working class concerns and "should not be dismissed as a possible source of stress" (p. 693).

Adolescent Employment and Family Life

A unique contribution to literature addressing work and youth has been that of Greenberger and Steinberg (1980, 1982). Their ecological approach, while limited by its methodology, makes substantial progress toward an understanding of the nature of teenager's work and family life by including documentation of specific jobs teens are now holding and on-site behavioral observation of actual job activity (Greenberger, Steinberg, and Ruggiero, 1982). The Greenberger, et al., (1980) study presents two major questions: (1) which kinds of psychosocial development are promoted by events and interactions within the workplace (i.e., increased self reliance, greater sense of responsibility, cooperative attitudes), and (2) what effects does working have on events and interactions that take place in other settings of adolescent life? li.e., effects on time spent with friends and family, or position 
of greater autonomy within the family)? Results of the study addressed the later question and indicated that, not unexpectedly, working reduced the amount of time that an adolescent spent with his or her family, and reduced the number of times the adolescent ate dinner with his or her family. The study used several indices of family interaction to measure the quality of relationship to family members. The authors found no significant differences between workers and non-workers attributable to work regarding: (1) how close the adolescent felt to specific family members, (2) willingness to discuss personal problems with family members, (3) degree to which the adolescent was involved in decision making, and (4) the effect of work on family rules regarding homework, household chores, and social life. In addition, the quality of the workers' relationship with peers outside the workplace was found to be unimpaired by work.

In contrast to family relationships, relationships with people at work were found to be far less positive than relationships with people outside the workplace.

Greenberger, et al., (198ø) posed two questions with regard to relationships with people at work: (1) Do relationships with people at work vary as a function of how often an adolescent works and for what period of time the individual has held the job, and, (2) How important are relationships with people at work relative to other relationships in the adolescent's life? Results indicated that although 
relationships with people at work were far less intimate than those with people outside of work, work relationships were unaffected by number of hours spent at work or the length of time the adolescent had held a job. Greenberger, et al., (1980) also reported that young people felt less close to their supervisors than anyone else with the exception of their favorite teacher at school. They were less likely to talk to their supervisor at work about a personal problem than anyone else, again with the exception of their favorite teacher.

Similarly, best friends at work were seen as being less intimate relationships than most other relationships in the adolescent's life (Greenberger, 1986). Workers reported roughly equal levels of intimacy with their father and their best friend at work, but were considerably more intimate with their favorite friend at work than with their favorite teacher.

While the questions addressed in the literature about youth and work are interesting, the research methods used typically evoke superficial responses from the workers. This problem may be merely a characteristic of the use of quantitative measurement in survey research. In the Greenberger, et al., (1980) study, for example, the question of perceived emotional distance from the adolescent's employer vs. best friend or favored teacher is raised. While the notion of distance in these 
relationships is interesting, its heuristic value is greatly increased by the possibility of a whole series of more in depth questions about the quality of those relationships. When the researcher is interested in the phenomenology of the experience of work, limitations of questionnaire data are most evident; more specifically, the absence of any use of follow-up questions.

This non-phenomenological view, or one which fails to take account of the perceived quality of events, characterizes the existing literature on adolescent employment. This is evident, for example, in the notion of work as a way of acquiring self-discipline (Timpane et al., 1976; Zajchowski, 1978). The notion of work as a path toward "socialization of adolescents into the adult world" is a view that is widely accepted as a positive aspect of the work experience. But, in fact, without understanding the opposing interests commonly seen in the struggle adolescents have with work-related learning, research is not getting at the real question of whether this kind of socialization is necessarily good for teenagers. Do youngsters acquire this "self-discipline" through prosocial compliance or is it based on the fear children acquire of authority? Is it based on a sense of the protective aspects of authority figures or on a sense of the repressive aspects of authority? In the same way, I might be more interested in the particulars of the potential 
struggle adolescents have with routine work rather than the simple reporting of its "effects." The lack of any clear data addressing the issue of workers' perception of the structure of work or their patterns of resistance to work demands presents a potential new area of field research. In this study, I raise questions about the quality of social understanding teens acquire in the workplace. Do class differences play a significant role in the adolescent's response to the work or her expectations for self-development? What are the contributions of the family's social class to the adolescent worker's perceptions of the intrinsic rewards of work? Given the existing limitations of questionnaire research on adolescent employment taped interviews were used in this study. Interview data were useful in two ways. First, it provided qualitative answers for research questions one through six (see Appendix A). Second, it provided data which was analyzed quantitatively to test the set of hypotheses described below.

While the predictions formulated in this study emerge from research into adult social class, they are essentially exploratory and reflect the exploratory nature of the study. I began with two predictions. First, using social class as the predictor variable in crosstabulation with responses to questions regarding relationships with co-workers, I tested the hypothesis that adolescents from 
working class families would be more cooperative and adolescents from managerial and entrepreneurial families would be more competitive in their stances toward co-workers. This prediction grows from Kohn's research described earlier suggesting that class background is influential in forming the interpretive framework an adolescent carries into the workplace. Kohn (1977) asserts that is is largely the differential effects of discipline and family work structure which account for social class differences such as those I expect. In addition, working class workers are more economically dependent on the jobs they have and enjoy less mobility than middle class workers (Nelkin and Brown, 1984; Garson, 1977). Second, I expected that middle class (managerial/ entrepreneurial family origins) adolescents would express more positive or idealized conceptions of managerial authority and that working class adolescents would be more critical or ambivalent toward managerial authority. This prediction was also tested using social class as the predictor variable and crosstabulated with responses to questions regarding relationships with managers. Here, too, the prediction emerges from the research Kohn presents which suggests that adult workers in middle class positions report a greater affiliation with managerial authority whereas working class respondents are more likely to report allegiance to authority (following the letter of the law) 
while their underlying feelings reflect ambivalent or critical values (Kohn, 1973). Several comparisons were made post-facto in this study. In an effort to explore the potential importance of job need and age in forming workers' values at work, I ran follow-up crosstabulations using job need and age as predictors. I reasoned that working for survival vs. extra money might indeed influence the respondent's view of work with regard to, for example, willingness to tolerate unfairness. The crosstabulations using age as a predictor, while also exploratory, did emerge from research described earlier suggesting that adolescent work is detrimental to the development of adult role aspirations. Questions about the acquisition of the detrimental effects are as yet unanswered. I sought to develop some ground work for a study of the age differences in attitudes toward work. 
CHAPTER II

METHOD

\section{Participants}

Participants were forty female nonmanagerial employees between the ages of 15 and 20 years (mean=17 years) who work part-time at one of eight McDonald's franchise stores in the Portland, Oregon area. There were three reasons for forming an all-female sample. First, McDonald's hires primarily female service workers. Second, I wanted to eliminate gender as a source of variance in the findings. And third, I was particularly interested in women and service sector work. In order to make class comparisons, participants were drawn from stores in both predominantly middle class and predominantly working class neighborhoods. (Managers tend to draw on the immediate area in hiring entry level employees). My aim was to form two groups of equal size: one group comprised of adolescents from working class families $(\mathrm{N}=20)$ and another group of adolescents from middle class families ( $N=2 \varnothing)$.

One long-standing area of debate within the Marxist literature concerns the nature and political importance of the distinction between the middle and working classes. 
While a review of these debates is beyond the scope of this paper, it is important to specify the basis for my own criteria in making class comparisons. One issue is whether or not professional and technical workers who, like other workers, have to sell their labor power to employers, are part of the working class or part of the middle class, i.e., small business owners, entrepreneurs and managers. This is partly a political question because it concerns the readiness of these nonmanagerial professional and technical workers, who are in an ambiguous and contradictory class position, to form political alliances with other workers (see: Aronowitz, 1973; Oppenheimer, 1985). While this remains an important theoretical and empirical issue, I agree with those researchers who use ownership and control as the primary criteria in defining class location rather than ambiguous terms such as "professional status" or "white collar work" (Kohn, 1973; 1977; Aronowitz, 1973; Edwards, 1979). Thus, nonmanagerial professional and technical workers who are not self-employed are included in our working class group. Small business owners, self-employed professionals, managers and administrators are considered middle class here in that they have a degree of control over their own work and that of others which sets them apart from--and sometimes in conflict with--working class people. At the same time, we recognize the potential for ambiguous and overlapping positions that 
adheres in making class distinctions.

Determination of social class standing, thus, was based on the work history of the subjects' parents and judged using 3 criteria: (1) supporting parent's occupation, 2) managerial-entrepreneurial vs. nonmanagerial supervisory or worker status, (3) salary vs. wage income. Research participants were all nonmanagerial food-service employees.

\section{Procedure}

Pretesting. Eight practice interviews were tape-recorded drawing on participants selected from a pool of Psychology 204 students currently attending Portland State University. All pretest participants met the criteria stated for use in the actual data collection and were informed of the voluntary nature of their participation. Practice interviews were used to refine the interview schedule and develop greater ease of administration.

\section{Recruitment of Participants. Participants were} recruited by Dr. Janice Haaken and myself during on-site visits at the eight McDonald's stores. Access to the restaurants was authorized by franchise owner, W.C. Gilbert. Consent was given to contact the managers at the 9th and Alder, West Burnside, Beaverton-Hillsdale, Cedar 
Hills, Aloha, N.W. 185th, and Hillsboro McDonald's stores for the purpose of on-site scheduling of interviews and informal observations of the work activity. Our strategy for recruiting participants was as follows. First, we attempted to interact as little as possible with store managers to avoid the appearance of an alliance with management. (In our experience, this is extremely important.) second, we sought permission from on-site managers to wait in the employee lounge which provided the only reasonable place for discussing the study with potential participants and soliciting participation. As employees came in during their breaks, we explained who we were, making a point of clarifying that we were not connected with the corporation or with management. Third, we emphasized our stance as "learners." For example, we typically said something like the following: "Many people in universities have written articles about teenagers who work--whether its good or bad for teenagers to work. Most of the people who have done these studies haven't really talked with teenagers about their work experiences and how they feel about them. We're interested in doing that." After explaining the study, potential participants (under 20 years of age or having turned 20 within the last three months while having worked at MeDonald's for at least a year) were asked if they would be willing to be contacted by one of the researchers for a one to one and a half hour interview. All participants were asked to provide prior 
written consent for the interviews. In addition, parental consent was obtained for participants under the age of 18 . The consent form appears in Appendix B.

Interviews were tape recorded and conducted at a site of the participant's choosing. All interviews were conducted by the second author, a clinically-trained psychology graduate student, over a period of 10 months. Tape recordings were identified in code prior to transcription. Table I lists the questions selected for the interview. Appendix A outlines the initial strategy for question selection. Questions covering standard demographic information and questions which probed four areas sequentially were presented: I) reasons for seeking work and the nature of the work, 2) relations with coworkers and managers, 3) conceptions of organizational structure, and 4) parents occupations and family experiences related to work. Standard practice was used to keep participants blind to the research hypotheses and to the predictor variable, i.e., social class.

Data Analysis. Content analysis of the tape recorded interview material proceeded as follows. First, as the study progressed, I reviewed the responses to questions concerning parents' employment in order to assure a distribution of two equal size groups (this influenced our choices of stores in which to recruit participants). I did end up with two groups of twenty participants $(N=40)$. 
Sociological experts were consulted in judging social class, based on criteria discussed earlier. All interviews were transcribed with subsequent data analysis involving written transcriptions. The second phase involved careful reading of the transcribed material to identify dominant themes related to my theoretical interests. The third phase involved content analysis of the interview material on an item by item basis. Table II lists questions used in the data analysis and defines the subsequent category content. Responses to 22 key interview questions were selected on the basis of thematic content. Specific conceptual categories were then identified, and criteria for selection elaborated, which allowed ratings to be made of all forty responses to each question. All categories were mutually exclusive and exhaustive in order to permit categorization of all responses. A two-way chi square test was done, using the factors of the adolescent's social class and the thematic categories associated with each question. Table III (p. 66) provides a statistical summary of the findings.

Categories were sometimes collapsed from complex ( $2 \mathrm{x}$ 3 or larger) to simple contingency tables $(2 \times 2)$ using two criteria. First, the complex table needed to yield results near enough to the .05 level to suggest that reducing variation due to the number of degrees of freedom would strengthen the results significantly. Secondly, two or more existing categories needed to be related in such a way 
as to be mutually nonexclusive such that two or more categories could be retitled as one category. If the existing categories failed to lend themselves easily to retitling, the row or column accounting for the greatest chi square value was singled out and known as category \#1 while the remaining categories were retitled as a single category, \#2, or "other." Crosstabulations were then statistically reanalysed.

Rater reliability. This statistic was calculated using procedures appropriate to nominal data. Two raters from a pool of undergraduate level psychology students at Portland state University were trained and asked to make independent category choices from the transcribed interview material on a subject by subject, item by item basis. Both raters were blind to the hypotheses of the study. Percentage of agreement was calculated using Cohen's Kappa statistic (Sacket, 1978) and ranged from .72 to .94. Final category selection was based on raters' agreements; disagreements were settled by the researchers. Appendix D provides a summary of the reliability profile. 
INTERVIEW QUESTIONS

\section{Background Questions}

1. How old are you? ACE

2. How long have you worked at McDonald's? IENGGH

3. How did you choose McDonald's for work?

4. At the time you applied, what choices did you have for work?

5. Why did you decide to find a job at all? WHYJOB

6. At the time you applied, what did you expect it would be like working there?

Trasks and Training

7. What kind of training were you given initially? TRAIN

8. Describe the order of the tasks that you loerned during the training period?

9. Toll me anything you remember about your early reactions to the training. (social and technical) REACT

10. What was your first assignent? Descriptions of work activity.

11. In the course of your day what opportunities are there to learn new things? IEARN

12. What kinds of decisions can you make about how to do the work? DFCDE

Organizational Structure

13. How do people move to a higher level job? MOVE

14. How far up would you like to nove?

Social Relations With Co-workers

15. Describe your interactions with other employes. COWORK

16. Can you tell me authing you remember about your early feelings to the other employees?

17. What kinds of things made you feel good about your job? GOOD

18. What kinds of things bothered you about your job? BAD

Social relations With Management

19. How is this store related to the the corporation?

20. How do the owners influence what goes on at the store?

21. What do you as an employee meen to the owmers? MEAN

22. That differences are there between in-store managers and franchise supervisors?

23. Can you tell me anything you remember about your early feelings about the in-store managers? 
TABLE I (contimed)

Manage

24. Can you tell me anything you remember about your early feelings about the franchise supervisors?

3. What is the store manager's job?

26. Do you think there is a ned for a manager?

27. What would it be like without a manager?

28. Describe your interactions with the management. INIMAN

29. How do they get people to do things?

30. Are there incentives the company offer you to work harder?

Organizational Structure and Change

31. Are there things that you do to make your job easier, more interesting, or pass the time? EASE

32. Are there things you can do with the other workers that make your job better in scme WRy? BEHIIRR

33. What kinds of things do you do after work?

34. Do employees have an organized way of talking about their concerns apart from the management?

35. Are there things about the job which seem unfair or are not right? UNFAIR

36. Do you think the pay and benefits are fair?

37. How would you deal with unfairness in your work? DFAL

38. Wy is it rum the it is? WHY

39. Describe some ways in wich your workplace could be made a better place to work? IMPROVE

40. How would that happen?

41. Why do you think there is no employees' union at MaDonald's? UNION

42. Do you think these kinds of jobs are good for teenagers?

43. What about authority do you learn at this job?

44. Do you think there is a greater use of cigarettes, drugs and alcohol among working teengers?

\section{Fanily Iife and Work}

45. What kind of work do your parents do? (kind of work, salary or wage, self-employed, level of supervision) CIASS

46. How do you think your parents feel about their jobs?

47. What about the woy you were raised influenced how you handle your job?

48. That jobs or responsibilities did you have at hame?

49. What heppened if you didn't do those things? CON

50. Is there arything you would change about the Fules for work at hame?

51. Were there things that you learned at hame that helped you when you started working outside? HEHP

52. What do you think your parents want you to get out of the experience of working as a teenager?

53. What do you imagine yourself doing when you are older?

54. In wat was do you see McDonald's preparing you to do that?

55. What do your parents expect you will be doing as an adult?

* Words in upper case denote code word used in the analysis. 
TABLE II

DEFINITION OF TERMS

The following table describes the categorizing of responses to the questions actually used in the analysis. Respanses to questions not appearing here were not used in the crosstabulation and are summarized in appendix A.

Respondent's Background

Q1: How old are you? ACE +* 1 1. 16 years 2 2. 16 years

Q2: How lang heve you worked at McDonald's? IENGIH
1. 1 mo.
3. 1-2 grs.
2. 1 mo. -1 yr.
4. 2 प्रrs.

Q5: How did you choose McDonald's for work? WHYJOB + *

1. Survival, basic income.

"I wanted to be able to put nyself...to be able to live on my owm."

"If I get my hours cut, I can't pay my bills."

2. Extra Money, college savings.

"I wented mi own maney...spending money."

"I needed to get maney for college."

3. Self development.

"It gives me time to think things out...evens my time out."

"I wented to get out of the house... to work away from hame."

Task Orientation and the Training Period

Q7: What kind of training were you given initially? TRATN *

Q9: Tell me aything you remember about your early reactions to the training. REACT *

1. Technical:

Respandents in this category describe the mechanical aspects of the training period, e.g., how the machinery works. These workers focus on the technical structure of the tasks without an affective companent. 
TABLE II (contimed)

"I didn"t like doing french fries. The way they do the french fries is really kinda stupid."

"...when you get up there and say you' re doing french fries... the holding time...its seven minutes... and when it goes off you just turn it off."

2. Other:

The three subthemes in this category, competitive, enthusiastic, and critical, seem to reflect evaluative components. Competition, for example, implies an evaluation of another's performance relative to ane's om. Establishing an overall thematic blend of these subthemes, however, was abandoned. Hence, the category "other" predominates.

"When I first started, I didn't think I was going to get along with anybody."

"I thought it was really hard. Like when you make mistakes, they really come down hard on you."

"It ras rlly exciting "cause it was new. I like a chellenge."

* Seme catagories as for question \#7

Q11: In the course of your day, what opportunities are there to learn new things? IEAPN

1. Focus on Problems:

Respandents here identify berriers, i.e., managerial interest in keeping workers unskilled or maintaining managerial cantrol over the labor process, favoritism, prejudice, misuse of incentives by managers, inadequate training.

"It depends on your manager. Most managers don't want to teach you anything that they don't think you to know."

"yy experience has been that the only way you learn anything extra is to come in on your off time."

2. Focus on Potential:

These workers identify the possibility for learning social skills, i.e., how to talk to people, how to get along with people; technical skills, i.e., grill temperature, shake mix ingredients, how to tally newly prepered food (calling shots), and/or opening and closing the store.

"If you work at McDonald's, you get to interact with the public. You learn how to deal with the public."

"You learn how to rum the cash register, and to "call shots," make shake mix and stuff like that."

Q13: How do people move to higher level jobs? MOVE *

1. Seme Knowledge of Hierarchy: 
TABLE II (contimed)

Respondent offers same knowledge of the hierarchical structure. Respondents in this category fell into two subgroups.

a. The potential for moving up is minimel, i.e., pramotion besed on individual merit is very unlikely. Mamagement is reluctant to move crew to management positions. Generally pessimistic about actually moving up.

b. Promotion is besed on Individual Merit: Upward mobility dependent on the abilities and motivation of the individual, or the extent or length of experience.

"There's really not much you can do. Just work harder and harder, get faster and faster and then you get a raise. Moving up is not really possible."

", he pramoted two guys who used to be employees. Now they are both managers and they are also really good friends of his. Plus, his wife, who was his fiance at the time, became a manager."

2. No knowledge, does not know, no explanations given.

"I really don't know... I don't went to be a manager."

Social Relations With Nanagement and Co-Workers

Q15: Describe your interactions with other employees. COWCRK

1. Conflictive:

Respondents here report scme emotional investment in relationships with co-workers, i.e., desire for closeness or very interested in co-workers, but they are aware of same obstacle or berrier. The barrier may be psychological, interpersconal or organizational. They describe feeling angry with co-workers, "persomality conflicts," "blowing up" at people or same upsetting situation which interfered with achieving closeness with co-workers. This category does not include respanses where co-workers are upset and/or where respondent takes pleasure in or justifies same advantage over co-workers.

"If you make a mistake... they never forgive you.... They are just standing there waiting for you to take a fall."

"I've alweys had a hard time getting elong with girls and women. I never really had friends at school. (At work) most of the girls are older... and I feel that if I earn their respect, then they' 17 do the same."

\section{Close, cooperative:}

Respondent describes having "fun" with co-workers, helping each other, sharing, being a "teem," getting together outside of work or living together, being like a "family."

"You always kinda have a positive outlook "cause you know you have to work with them so, you know, you try to make friends."

"They were all really mice and tried to meke me feel comfortable...and they worked with me and answered all of my dumb questions." 
TABLE II (contimed)

3. Competitive or Aloof:

Respondent describes interactions as friendly but emotionally distant, or alludes to feeling superior to co-workers or looking down on them. When describing co-workers in pasitive terms, implies social politeness, 9.g., "people are very nice," "I sey Hi to everyone." Little evidence of real emotional investment in relationships with co-workers.

"I feel kinda bad about it, when I came I was older than everybody. I had been to a year of college so I was kinda looking down my nose at everybody."

"I could tell right away who were the soobs and who the shy people and who were the ones that didn't went to get their fingers greasy. You had to learn to work aroumd it if you manted to get in."

Q17: What kinds of things do you like about your job? GOOD

1. Rewards are derived from management or hierarchy:

Respondent describes emotional or social rewards from managers or comparing herself favorably, vis a vis co-workers. Kay express feeling superior to co-workers. Liking to be complimented by managers. This does not include benefits such as time off, extra break time, increase in where no mention is made of their symbolic meaning, e.g., "It made me feel appreciated."

"Getting a good pat on the back (from the managers.)"

"Like ruming the bin during lumch and afterwards having the manager came up and tell you that you did a good job."

2. Rewards derived from interactions with co-workers or customers:

Reports feeling good about getting a smile from a customer, joking aroumd with co-workers and custamers.

"You meet a lot of kids here and if you make them smile it feels good to you too."

"If I please the customer, that makes me feel good."

3. Rewards derived from intrinsic aspects of the job:

Describes feeling good about being fast, completing a difficult task, being able to demanstrate "knowing a lot."

"When I do a good job... when I get the food roady really quick."

"Well, when I heard there was going to be a test...working breakfast was a test and it felt good to hear people saying it was going to be tough and it was a challenge."

4. Rewards derived from extrinsic aspects of the job:

Respandent reports seeing no value beyond getting wages, breaks, days off or preferred hours. 
TABLE II (contimed)

"Nothing makes me feel good except getting the check and depositing it."

"Well, I ve been here a lang time... I just look forward to going hame at night."

Q18: What kinds of things bothered you about your job? BAD

1. Focus an people or relationships with people:

Respandent reports being bothered by management/hierarchy and/or coworkers/custamers. Respandent may describe feeling controlled or exploited by maragers. Being called in unexpectedly, mamagers overlooking break allocation and/or management overlooking the besic neods of the workers, e.g., the candition of the break rocm, repair of facilities or machines in the store. In addition, they mey mention getting a rude remark from a customer, other workers being too bossy or unfriendly, other workers not pulling their own weight, workers complaining too much about the work or conditions of work.

"You get really frustrated "cause you work so lang and hard and never get any appreciation for it."

"Poople that down talk McDomald's"

2. Focus on the work:

Respondents here are bothered by events/activities involving intrinsic or extrinsic aspects of the job, e.g., pace too fast, training practice and/or time allowed for training is seen as inadequate. They are bothered by their ormlimitations, e.g., making too many mistakes, not being able to keep up wi th the work. Respondents may mention being dissatisfied with low wages, missed or shortened breaks due to a sudden rush, not getting days off or preferred hours.

"Being rushed through the training. There's a lot even now that I don't know how to do."

"The fact that it was fast and it had to be fast."

3. Not bothered by anything about the job:

"Nothing much... Im just glad to be working instead of sitting home in front of the TV."

Q21: What do you as an employee mean to the managenent? MEAN

1. Exploitive:

The emphasis in this category is on managanent as having the sole interest in making money off the workers. The worker here feels little reciprocal dependency from mamagenent. Feels easily replaced or dispensable.

"(Leaghing) Diddly squat! They con dispense with me enytime. They don't care. You have a little mmber and when they are through with you, they give your muber to scmeone else."

"Rothing... because I'm part of a chain and there's a certain group of us that work together...like a well-oiled machine." 
TABLE II (contimed)

\section{Exploitive dependency:}

The ormers use the workers but also depend an them. Emphasis here not so much on being replaceable as an providing skills or services upan which mamegement depends. This relationship is described as a parasitic, unequal, or exploitive one.

"In an employee and I'm there to have a smile on my face at all times and look happy and do what they need to do."

"Codar Hillls does the most volume but I don't think they really care about that."

\section{Persoral dependency:}

Managers or company described as neding her as an individual. Workers may see themselves as on extension of the ommers, e.g., "We kep the store going for them, he needs us to be there or we help the store work." There is no mention here of conflict or exploitation. The respondent mention striving to demanstrate dependability to owners or feeling exceptionally cared for.

"I think we are pretty valuable to them... they make the rules and we work for them... I think they have to watch how they treat us. They cen"t afford to have twenty people up and quit on them."

"Well, I called in sick a lot last year and they didn"t can me. I guess I'm pretty important if they did that."

4. Ambiguous/don't know:

Expresses vague or conflicting sentiments or doesn"t express an opinion.

"I dan"t know... they replaced check when I lost it...so I guess they care...but then...I don"t really know."

R23: Can you tell me anything you remember about your early foelings about the in-store manager? MANAGE

1. Critical:

Respandent describes managers as unnecessary. Reports that they do not help out when needed or that they dan $t$ do much. Managers may be viewed as abusive. This does not include criticisms of upper mangement when criticisms are limited to defending riddle mamegenent, e.g., "They took our good managers away."

"W first feeling was about what they do. Most of the crew people do the work, you know. Why are they there? And, cone time, I asked then, I said, "You're a manager, I men you hardly do anything." He said, "Well, if a situation arises that's really hard to handle, I lll be respansible."

"He really gets on my nervee because he says if you want a day off in advence, put a note in wo bax and I ll try to give you that day off, so you put a note in his bax and he elvays schedules you for that day. You ask him about it and he says he never got the note. So he goes and looks for it and it's still in the bax. It's like he never even looks for it." 
TABIE II (contimed)

\section{Affilial:}

Respondent reports wanting to be liked by managers as friends. The emphasis here is an affection for manegers, personel attachent, flirtations, repeated emphasis on friendliness. May be angry about withdrawel of affection or describe feeling upset about being yelled at. Competition with co-workers for managerial status is also included here.

"He said, "I have a good feeling about you. You have a nice smile." That made me feel really good. I felt that he was the most personable of all the managers, and that he really wanted to help; wanted me to like working there."

"They were really supportive because I had no friends there. was reelly nice. He helped me out a lot, and he was my friend and wanted me to be comfortable and made sure that I was $O K$. He said if I had any problems with anybody that I could just come and tell him."

3. Ceutious:

Respondents emphasize getting along but also report feeling scared. "They were nice but kept an eye on you." They may mention heving to be nice to get more scheduled hours of work.

"Well, they were helpfur in a bay but also really moro bossy. I didn't really understand anything, I didn"t koow some things, so I had to keep an open mind. I didn't want to get mad at anybody, cause I get mad at people ensy."

"I was a little intimidated. When you first start a job, managers are almost scary sort of. You know, you better not do this or that or the manager's gonna catch you and you're going to get in trouble."

"I was kind of scared of her. Every time she"d came through the door I"d spill samething. I was afraid of getting on her bed side."

Q28: Describe your interactions with the managers. INIMAN *

1. Positive or idealized:

Respondents express the for having scmeone "in charge," or for developing personal friendships with managers, (as distinct from just "friendliness"). There is idealized quality about the respondent's image of hierarchy. They to take pleasure in flirtation with mangers, being like family.

"I can call him up if there is a question, at hame even. If we have scmething wrong that's a persanal problem... I like that feeling that there is sameane there for me in case samething happens."

"Oh, the store manager is just like Dad, he's the big, you know. It's really nice to heve a management teem that you can roelly feel close to."

2. Other:

a. Formal compliance: 
TABIE II (contimed)

Respondent describes an ability to get along with managers, or a "friendliness" with management as opposed to a "friends" or special relationship.

"With the managers it's more of a working relationship than with the crew poople, who are more your friends. Same people are really good friends with the managers... really close."

"I work with most of the managers good....most of the time....all but don't usually say anything to me and I just try to get along with them. - They

b. Avoidant or critical:

Respondents report attempts to stay out of the way of manegers. Managers are seen as having the potential for taking out frustrations on the workers. Worker describes more negative interactions, describes being more comfortable or friendly with co-workers then bosses.

"One time, this manager went out of the store and left with a rush and didn"t bother to get us help or anything. We were short 2 people and he just left. That got me rolly mad and I told the district manager."

"You feel a distance between you and the manager. I feel like they just take adventage of their position and slack off."

Organizational Structure and Change

Q31: Are there things that you can do to make your job easier in same way? EASE

1. Enotional/Social Resistances:

Respanses fell into two subgroups:

a. Fnotion Management: Respondents report maintaining control over their own emotions, they "try not to lose it." Try to "get alang" with everybody. They report learning not to care about the quality of the work and try to avoid watching the clock.

"There are same things you have to just ignore. You have to learn not to get mad." "Not watch the clock...not get wrapped up in how the work is done right or wrang... and now I just heve such a light attitude. I just do my job and kinda keep to myself...talk to people but not let McDonald's become my whole life."

b. Social Interaction with co-workers or custamers: These respandents report learning to work together as a teem by creating toem game strategies to lighten the pressure. Many report, for example, doubling up to lessen the pressure of the pace. The practice of "doubling up" is often resented by management who, unless the work is restructured, is forced to bare the sight of unoccupied workers.

"Once in anhile two people will do the same job. That helps a little...but it's basically relly boring when it's not busy."

"Well, since we are all really close we can laugh and joke and when one of us is in a bed mood the other can bring us out of it." 
TABLE II (contimed)

2. Technical Resistance:

a. Resisting or altering the pace or nature of work: Respondents beep busy by staying ahead of the work/pace. Respandents try tolook busy or look for ways to "get awey from it all," find things to do before being told to do sanething. They may report developing shortcuts, altering prescribed order of tasks.

"Keep busy... it makes the time pass faster...find odds and ends to do." pride in the work.

b. Respandents describe altering the nature of work: developing a personal

"You can sometimes, if its slow, clean things really well." "If you're a good worker, you'll stay busy." "I like it when it's busy."

Note: Care was taken to differentiate between "being busy" and "keeping busy." The former is a "pace" resistance, the latter a control over pace and emotionel resistance, being "out of the managers eye."

Q32: Are there things that you can do with the other workers that make your job better in some wy? BEITHR

1. Close/Cooperative:

Respandents here report attempting to develop positive emotional ties with their co-workers. They report trying to help och other out, share personal problems, share expressions of hostility against McDonald's. Working as a team is included here when this is described as a form of emotional support or reciprocity, e.g., "I help her and she helps me." Same respandents express dissatisfaction with competition in or outside the workplace.

"If scmeone has problems, you help them out. They're friends. Sometimes they"re short of money or in a bind and you help them out...lend them money. Same are young and if they noed advice... I get asked advice a lot."

"We do things in team work instead of individuals, it's a lot flumer, and even if you make a game out of it. You race gainst each other."

\section{Aloof/Disdainful or Functional Amiability:}

Respandents here report attempts to avoid getting on the "bad side" of co-workers or complaining about co-workers. The emphasis is an trying to "get along" with co-workers, trying to develop better working relations. The company besebell teem was the primary example given of the effort put forth in this regard, though the interaction was not alwass considered positive. Same respondents seemed to enjoy the competition more than cooperative close relaticnships; scme were critical of co-workers that didn"t work as will or as hard. There of ten little desire for interaction. "Getting to know people may be merely a way of avoiding boredom."

"You have to work together. That"s besically it. You know, ya just have to get alang and work together. The besebell teem is a good idea even though it's such 
TABIE II (contimued)

harsh competition ance you get out there. I don't know what happens ance we get out there, 'cause we are such good friends when we start... and then we get out there and, ya know, "You should have caught that fly ball... we just get med at each other cause we don"t win."

Q35: Are there things about the job wich seem unfair or are not right? UNFAJR *

1. Exploitation concerns:

Respondents in this group were critical of speed ups, the redundancy of the work, cutting of hours, having to work off the clock, and/or the imadequacy of the food allowance. Favoritism was included here when the respandent identified feeling pitted against another worker or when the reasons for fevoritism are unspecified. Also included were responses to feeling oppressed, i.e., being in a service position.

"People getting more hours then you when ou're equal and not getting more fevors. That's not fair."

"Yeah... then hiring so many people and...not giving "en enough hours. If they wouldn't hire so many people they could give "um the hours... heve you heard about that?"

2. Interpersanal concerns or non-critical:

a. Reports of not being treated nicely, being yelled at, wanting to be preferred by managers over co-workers were included here.

b. Noncritical.

"I think it's unfair that same of the managers are really rude... even though you try so hard... they"re still really rude... and you can"t ever really say what you feel."

"I don"t really think there is anything unfair."

Q7: How would you deal with unfaimess in your work? DEAL *

1. Telk to mamagers:

Respondents in this category emphasized appeals to the managerial hierarchy with complants or issues of unfairness at work.

"I would probably talk to the manager...ask to sit down and talk to him."

"If you really went to get things done you go the the head office."

2. Fndure; nothing can be done or passive resistance:

Wost respondents in this category emphasized a helpless feeling in response to unfaimess. They reported feeling hopeless and trapped by the company. Some respondents reported passive resistance, e.g., slowing the pace, giving away food, or attenpting to solicit group solidarity. 
TABLE II (contimed)

"You relly can"t do anything. I mean you don"t have any say. I've said stuff before and nothing ever changes. Never does! They are set in their ways and they're not going to change."

"A lot of things you really can"t change. There isn"t anything you can do and you just have to lot it slide by."

Q38: Why do you think it is $\mathrm{nm}$ the it is? WHY *

1. Efficiency:

Respondents here viewed the company positively. Things rumning smoothly or the fast pace were viewed as virtues in and of themselves. These workers sew the "system" developed at McDonald's is more scientific and, thus, positive or progressive.

"For efficiency, for speed. They want to get out the most food in the fastest time possible."

"Efficiency, I think it's the most efficient wat it could be. It's gotta be fast to work well."

"Well, you're always going to have to try to have a high profit margin. That's number one."

2. Other:

a. Profit:

Here, the company's motives are profit oriented. The system is set up as a means of increasing profits. Efficiency here is seen as a way of extracting more from worker, increasing sales, and/or maintaining a competitive advantage in the fast-food market. The response here is not positive. Respandents are critical of MaDonald's public relations and marketing strategies and/or McDonald's emphasis on image or conmercial factors.

"So they can make as much maney as possible. I think that's the whole point." "So they can compete (for profit) with other fast-food restaurants."

b. Personal Virtues, Capabilities, or Inadequacy:

In this category the compeny's emphasis an efficiency is seen as in the service of a personal cancern for custamer satisfaction and/or a personal interest in the workers or customers. Included are respanses with emphasis of the compeny's desire to "serve the conmmity." Iack of personal care for workers or lack of attention to interpersonal issues also appears here.

"They want to make it easy on the custamers and the kids who noed an easygoing job. They've set it up so they can get it out fast and get those workers to work." "I think the people go there for the service. Really fast service. The customers like it that was."

c. Does not know or no opinion expressed: 
TABIE II (contimed)

039: Describe same ways in which your workplace could be made a better place to work. IYPROVE

1. Psychological/individual change:

Respondents here desire change in the style of mangement, better attitude, more individual respect or status, pay based an individual effort, co-workers not pulling their orn weight.

"I think, first of all, that there should be more respect, just for each person... and a lot more tolerance. Fair pay, definitely! And, rather the raises for..." cause they" ve been there for so long... people should get raises "cause of the way they"re doin" their work."

"Kore spirited managers and crew...working together not tearing each other apert. The managers not yelling out every little thing the crew should do."

2. More equity/change in the labor process:

Respandent identifies discontent about speedups, pressure, low wages, lack of cantrol, inequities of various kinds, lack of social cohesivens anongst crew.

"Waybe if they did have crew meetings, they"d find that a lot of people feel reelly strong about who gets raises and who doesn" $t$. We work a lot harder than they do. (Their job) wrapping food is the easiest thing in the world."

3. Change in work emironment:

Respondent identifies discontent about the uniforms, crowded work areas, cleanliness, crew room or bathrocm.

"Different uniforms, probebly. I hate polyester. I hate working in a fast-food restaurant... roelly gross, really greasy."

"Cleaner! That place is so dirty... and they need same ammonia. All they use to clean is water. If the heel th people come they "ll be out of business."

"A softer floor."

4. Don't know/no change neoded or possible:

"I den't know. I think it's a pretty Ok place. I just went to work there and get a good reference when I leave."

Q41: Why do you think there is no employee union at MaDonald's? UNION

1. Youth of the workforce:

Respandents here feel that it is easier to exploit young people. They cite unemployment cmang young people and/or that young people don't take working seriously. 
TABIE II (contimed)

"Well, it's just kids here. We're not willing to invest that much time. Unions are for truckers and older people."

"It's just teenagers working there and if they don't like it they can just put up or get out. It's not like it's a lifetime job or anthing."

2. Unions as inconsistent with the structure of the work:

Here, respondents emphasize the assertion that workers are replaced easily, and/or that the low level of skill required at McDanald's makes workers interchangeable. They feel that pert time workers heve less investment in the work; they expect to be temporary. Thus, there is a high turnover rate which makes organizing more difficult. Respondent may focus on the greed of the owner, i.e., that employers don't want to pay. Sees the owner as thinking primarily about profit.

"Cruse they would all go an strike if they hed ane (laughing.) They all know we' re talking about it...ya know... let's picket...ya know....unfair treatment."

"Because you can get so many other people to fill in, do the work."

"Maybe it's because they dan't want people to demand certain things and get um."

3. Other: Never occurred to respondent, doesn't know:

"I dan't know. I don't rally know mich about a union."

Family Life and Work

Q45: What kind of work do your parents do? CLASS + *

1. Working Class or nomamagerial middle class:

Respondents were identified as coming from working class beckgroumds when the heed of their parental household was employed in namanagerial wage work.

\section{Middle Class:}

Respandents were identified as ocming from middle class backgrounds when the head of their parental household was either self-mployed or employed in a supervisory, selaried position.

Q49: What happened if you didn ${ }^{-} t$ do your jobs at hame? CoN

1. Compliant approach:

Pride in complying with expectations. Coupliance was seen as a successful means of avoiding criticism or avoiding being told what to do. Strict or harsh lessons of parents respanded to positively or with admiration, e.g., "She was right" (in being so strict).

\section{Matter of fact approach:}

Respandents here describe the consequences of nancompliance without much subjective respanse. Some struggle or consequence of nancompliance is identified followed by an 
TABLE II (contimed)

compliance, e.g., "then wid it." The emphesis here is not so much on uniform, imediate compliance or extreme goodness as it is on compliance in face of same struggle of fear of the cansequences. Fear of the cansequence might take the form of extreme disarray, i.e., "If I didn't do it, it didn't get done."

\section{Hostile/Conflictive:}

Respondents here describe feeling put down a lot and are, as a result, critical or angry with a parent.

Q51: Were there things at hame that helped you when you started working outside? HEIP *

1. Necessity of work/self cantrol:

The emphasis here is on the necessity of ecquiring a working knowledge of concrete tasks, e.g., cleaning or sweeping and/or heving to tolerate difficult working canditions. Respondents often felt they had learned to get along with others and to tolerate abuse or favoritian. They felt they had to work, e.g., "I didn"t have things given to me."

"I learned hoe to take criticism pretty well and there's a lot of times when the crew or managers will just blow up or something."

"Just that you work "cause you get paid and you'd got paid unless you work for it."

2. Abstract capabilities and/or Self development:

The emphasis for these workers is a having acquired self direction, having learned to "deal with people," "camunicate," "take initiative," "get respect." Learning to handle "different behaviors" or "different people's attitudes" was a frequent comment. References to the necessity of work were illustrated by contrasting it with awareness of available privileges, e.g., "I had to do things because we didn"t have a maid."

"To make sure you did your best and not to cut corners on it. Make sure they recognize that you did your best or tried to."

"We all had to help out around the house, cleaning up after meals and everything. I learned to work like that...we couldn't really afford a maid or anything."

+ Indicates prodictor

* Indicates that respanses yielded significant results

* Indicates dependent measure yielding significance in crosstabulations with more than one predictor. 
RESULTS

Tasks and Training

Class Differences in Approaches to Training. Five of

the 21 comparisons made with regard to social class and the four major areas of investigation, i.e., tasks and training, relations with managers and co-workers, organizational structure and change, and family life and work, yielded significant results. Questions and probes for attitudes and early feelings in response to the training period were useful in gaining information about class differences with regard to perceived social hierarchies at work, work distribution, and early strategies for coping with workplace pressures.

In response to the question, "Tell me what you remember about your early feelings about the training period," two categories are identified. First, the technical approach represents a focus on the details of the training period and an interest in how machinery and equipment work. These workers focus on the technical structure of the tasks. The second category could not be defined by any inclusive thematic content and is thus seen as other. However, three subthemes were considered which seem to be linked by an affective component. A competitive approach represents an awareness of the hierarchical nature 
of workplace relations and a preoccupation with competitive advantage vis a vis co-workers. An enthusiastic approach reflects the worker's excitement of having begun a new job or positive feelings about the training period with particular emphasis on the "newness" of the experience. The third subcategory, a critical approach, refers to a focus on abusive or exploitive aspects of work, e.g., dangerousness of the work, the menial and degrading aspects of the work. Results indicate that 558 of middle class respondents adopted a technical approach to learning during the training period in contrast to 258 of their working class co-workers. Working class respondents were more likely to adopt one of the "other" approaches to training, $\mathrm{x}^{2}(1)=3.80, \mathrm{p}<05$.

Social Relations with Co-workers and Management

\section{Class Differences in Relations with Managers and}

Co-workers. The major predictions of this study focuses on class differences in relations with managers and co-workers. The crosstabulations of social class categories with those regarding relations with co-workers (class $x$ co-worker, class $x$ better) produced insignificant results. However, crosstabulations of data regarding 
social class variables in relations with management resulted in a significantfinding. In response to the question, "Tell me about your interactions with the managers," (followed by probes for further explanations and examples), three identifiable themes emerged. The first category, positive or idealized, represents a tendency to form positive attachments to managers or to focus on the positive attributes of managers. An interest in forming a strong, personal attachment is seen here. The other major category, other, is subdivided into two themes. Formal compliance represents a desire to get along with managers in order to maintain a good working relationship. Here, artificially constructed relationships serve the purpose of "getting along." The operative distinction between this sub-theme and the former is that of "friendliness" (in the latter category) versus "wanting to be close friends" (in the former category). The second subtheme, avoidant or critical, involves expressed efforts to maintain distance, focusing on conflictual relations with managers, or rejecting managerial control. Consistent with my first prediction, 858 of the working class respondents fell into one of the two subcategories termed "other" in contrast to just 508 of the middle class respondents. Further, 508 of middle class respondents reported "positive of idealized" relationships with managers in contrast to just 158 of the working class respondents, $\mathrm{x}^{2}(1)=16.62, \mathrm{p}<\emptyset \emptyset 1$. 
Organizational structure and Change

Class Differences in Approaches to Resistance and

Mechanisms for Change. Class differences in resistance to workplace conditions emerged from two key questions. First, in response to the question "Why do you think the company is run the way it is?", participants were asked to identify a rationale for working conditions and the labor process thereby drawing on their capacity to conceptualize social processes and social institutions. Two dominant themes were associated with this response. The first category efficiency represents the view that the production systemat McDonald's is scientific and thus positive or progressive or that the way the company operates is proven efficient and therefore "good." The second category is classified other. Efficiency is described critically as a means of getting more out of the workers, increasing sales, and/or maintaining a competitive advantage in the fast-food market, e.g., "It's done this way because they need to be number one." Results of this crosstabulation suggested a middle class emphasis on efficiency, i.e., on the positive aspects of the McDonald's system. Eighty-one percent of the middle class respondents fell into the first category in contrast to 388 of working class adolescents, $\mathrm{x}^{2}(1)=6.86, \mathrm{p}<01$. 
In response to the question, "How would you deal with unfairness in your work?", respondents were asked to comment on their ideas about the potential and means for change. Two main themes emerged in the analysis of responses to this question. The first category, communication with management, focuses on communicating directly with management with the expectation that management would respond favorably to these efforts. The second category other, is a combination of two subthemes. The first subtheme, endure, involves an endorsement of passive resistance or stoicism in dealing with workplace grievances. The second subtheme characterized a small percentage of the responses $(12.58)$. It involves some form of individual or group defiance in dealing with workplace grievances. Resistance in this context did not always refer to a rejection of general social imperatives, e.g., resistance could emerge as a rejection of structural constraints in the workplace while preserving behaviors generally considered socially positive. For example, workers reported giving away extra catsup packets or ignoring time constraints while talking with customers. Eighty percent of middle class respondents fell into the first category in contrast to 408 of their working class co-workers, $\mathrm{x}^{2}(1)=6.66, \mathrm{p}<\varnothing 5$. 


\section{Motivations for Seeking Employment, Unfairness and}

Resistance. In attempting to gather information about the relationship between motivations for seeking employment and the relations of work several exploratory crosstabulations were performed. Of the total (21 comparisons), two produced significant results. Participants were asked, "Why did you decide to find a job at all?" Two categories emerged in responses to this question. First, the search for a job was motivated by subsistence needs. In this context subsistence refers to a need to work either to augment their parent's wage or to provide basic income for their own necessities. The second category, self-development or extras refers to those responses where job search was motivated by the desire for either "spending money," or money for college and/or that work is a context for learning skills useful in developing work related social skills. Initial assessment of the data revealed that thirty-two percent of all participants were working to provide a means for subsistence, sixty-seven percent worked for extra money and/or in the interest of self-development.

In the chi-square analysis, there was a significant interaction between job need (whyjob) and two other variables. First, in an effort to explore the adolescent's perception of the workplace grievances, participants were asked the following question, "Is there anything about your job which seems unfair or is not right?" Two categories 
were identified. In the first category, exploitation concerns are the primary focus. Respondents are critical of speed-ups, the redundancy of the work, cutting of hours, working off the clock, or food allowance inadequacy. The second category, Interpersonal concerns or non-critical consists of two subthemes. A preoccupation with interpersonal concerns is the main focus of the first subtheme. Not being treated nicely, being yelled at, or wanting to be preferred by managers over co-workers are concerns found in these responses. A non-critical position, e.g., defending of management and management's prerogatives, characterizes the second subtheme. Typically, respondents here view middle management as a benevolent influence. Management's overall aim is to provide a service to the publici the personal costs to employees are understood and accepted as fundamental and necessary. Forty-five percent of respondents working to meet basic financial needs fell in to the first category in contrast to 258 of respondents working to meet additional living expenses. Results indicate that respondents who work primarily for subsistence reasons were more likely to identify concerns about being exploited in their work, $\mathrm{x}^{2}(1)=6.84, \mathrm{p}>\emptyset 1$.

While adolescents working to meet subsistence needs were more likely to identify the exploitive aspects of the work than those working for "extra" money, these 
adolescents were also more likely to stoically endure perceived unfairness at work. Two major categories, one single category and two subthemes are associated with the question, "How would you deal with unfairness in your work?" These include stoic endurance, and other.

Subthemes of other were (a) talking to management, and (b) individual or group defiance. Fifty-four percent of respondents working to provide for basic needs fell into the stoic endurance category while just 158 of respondents working for other reasons fell into the same category. Results indicate that workers who are working for basic necessities are more likely to report stoic endurance as a means of dealing with unfairness in the workplace, $\mathrm{x}^{2}(1)=8.99, \mathrm{p}<01$.

Age Differences and Upward Mobility. Of the 21 comparisons made with age as the predictor, all but a single crosstabulation were insignificant. One question in the series of those aimed at gathering information about working adolescents' knowledge of the organizational structure produced significant though not surprising results. In response to the question "How do people move to higher level jobs?" respondents 17 years of age and older were more likely to report some knowledge of this process. They reported that either one moves up in the company through individual merit, i.e., that it is 
dependent upon the abilities and motivation of the individual worker, or the extent or length of experience, or that the potential for moving up is minimal, i.e., that individual merit is irrelevant and/or that moving up is dependent upon the likes and dislikes of management and, furthermore, is not influenced or altered by individual effort. In contrast, 15 and 16 year old workers reported no knowledge of the organizational structure, they simply said they did not know how one moves up. Results indicate that 448 of the respondents 15 and 16 years of age reported no knowledge of the means of upward mobility while less than 18 of the respondents over 17 gave similar responses, $\mathrm{x}^{2}(1)=11.51, \mathrm{p}<01$.

Family Life and Work

Questions about the carryover of family life into the workplace guided a major part of the study's organization. Social class interacted with responses to one question addressing the carryover of family life into the workplace. In response to the question, "Were there things that you learned at home that helped you when you started working outside?," themes fell into two categories. First, a focus on the necessity of work or self-discipline indicate an emphasis on the mandatory nature of housework, the need to tolerate or "control" feelings about family work, e.g. abuse and/or favoritism, or the "need" to work for what 
they had at home. These understandings associated with housework are viewed as helpful in adapting to the workplace. The second category, abstract capabilities or self-development, represents an emphasis on learning in the family to get along with people, communicate with others, or take initiative with others. The need for respect in relation to family work emerges from the view that self-respect or pride in one's work can be accentuated by contrasting it with an awareness of available privileges, e.g., "I had to do it all since we didn't have a maid." Eighty-five percent of working class respondents fell into the first category in contract to 458 of middle class respondents. Working class respondents tended to emphasize the necessity of work and self-discipline whereas middle class respondents more often focused on self-development and abstract capabilities associated with family work, $\mathrm{x}^{2}(1)=5.38, \mathrm{p}<65$.

TABLE III

STATISTICAL SUMMARY

CHI SQUARE ANALYSIS

\begin{tabular}{|c|c|c|c|}
\hline $\begin{array}{c}\text { Question \# } \\
7 \\
28 \\
37 \\
38 \\
51\end{array}$ & $\begin{array}{c}\text { Predictor } \\
\text { class } \\
\text { class } \\
\text { class } \\
\text { class } \\
\text { class }\end{array}$ & $\begin{array}{l}\text { Dependent Measure } \\
\text { train } \\
\text { intman } \\
\text { deal } \\
\text { why } \\
\text { help }\end{array}$ & 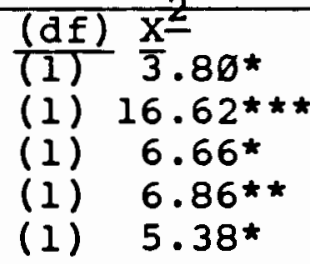 \\
\hline $\begin{array}{l}35 \\
37\end{array}$ & $\begin{array}{l}\text { why job } \\
\text { why job }\end{array}$ & $\begin{array}{l}\text { unfair } \\
\text { deal }\end{array}$ & $\begin{array}{l}6.84 * \star \\
8.99 * \star\end{array}$ \\
\hline 13 & age & move & (1) $11.51 \star \star \star$ \\
\hline
\end{tabular}


In concluding a review of the results of this study it is important to clarify the overall statistical significance of the data. Of the 55 questions with potential variability in responses, $n=5$ significant results were obtained when looking at social class as a predictor. As this is roughly 108 , or 58 more than would have been expected by chance alone, one may conclude that the social class predictor is probably an important determining factor in the outcome of the data. However, the $n=2$ significant comparisons each for age and whyjob are no greater than would be expected by chance alone; therefore I am inclined to view these results with more caution. 
CHAPTER III

\section{DISCUSSION}

The interview schedule followed an outline of four general areas of interest related to adolescents and the fast-food segment of service work: 1) tasks and training, 2) relations with managers and co-workers, 3) conceptions of organizational structure and change, and 4) family life. As illustrated in Figure 1, social class differences emerged in all four areas. Each of the four areas is presented graphically in the figure. Age differences and differences related to motivations for seeking employment were found to be related to perceived notions of organizational structure and change. Figure 2 provides a graphic representation of these findings.

A series of theoretical questions surrounding the work-family linkage fueled this research from the start. Previous research findings associated with social class background raise questions about the nature of the relationship between work and family. While more evidence has surfaced in favor of the "generalization hypothesis" or one which suggests that the work environment is an arena into which family life extends or "spills over," (Pleck, 
1977; Rosenberg, 1979; Mortimer and Lorence, 1979) others suggest that work and family life are linked by a kind of compensating dynamic. That is, the workplace compensates for the needed but absent functions of the family (Piotrkowski, 1978).

The predominance of one model over the other has not been established. It would seem that both models operate in varying degrees and with varying frequency in family and work linkages. In the present study of class differences, for example, results in the area of "tasks and training" suggest that values acquired in the family may "spillover" into the workplace. Adolescents from the middle class were more likely to adopt a technical approach to training. While the results of this study suggest the predominance of a "spillover" effect, questions about the predominance of one model over the other are perhaps not as important as the factors sustaining the existence of each. Some of the factors I have identified will be addressed in the following discussion of the results of this study. 
FIGURE 1

FINDINGS RELATED TO SOCIAL CLASS

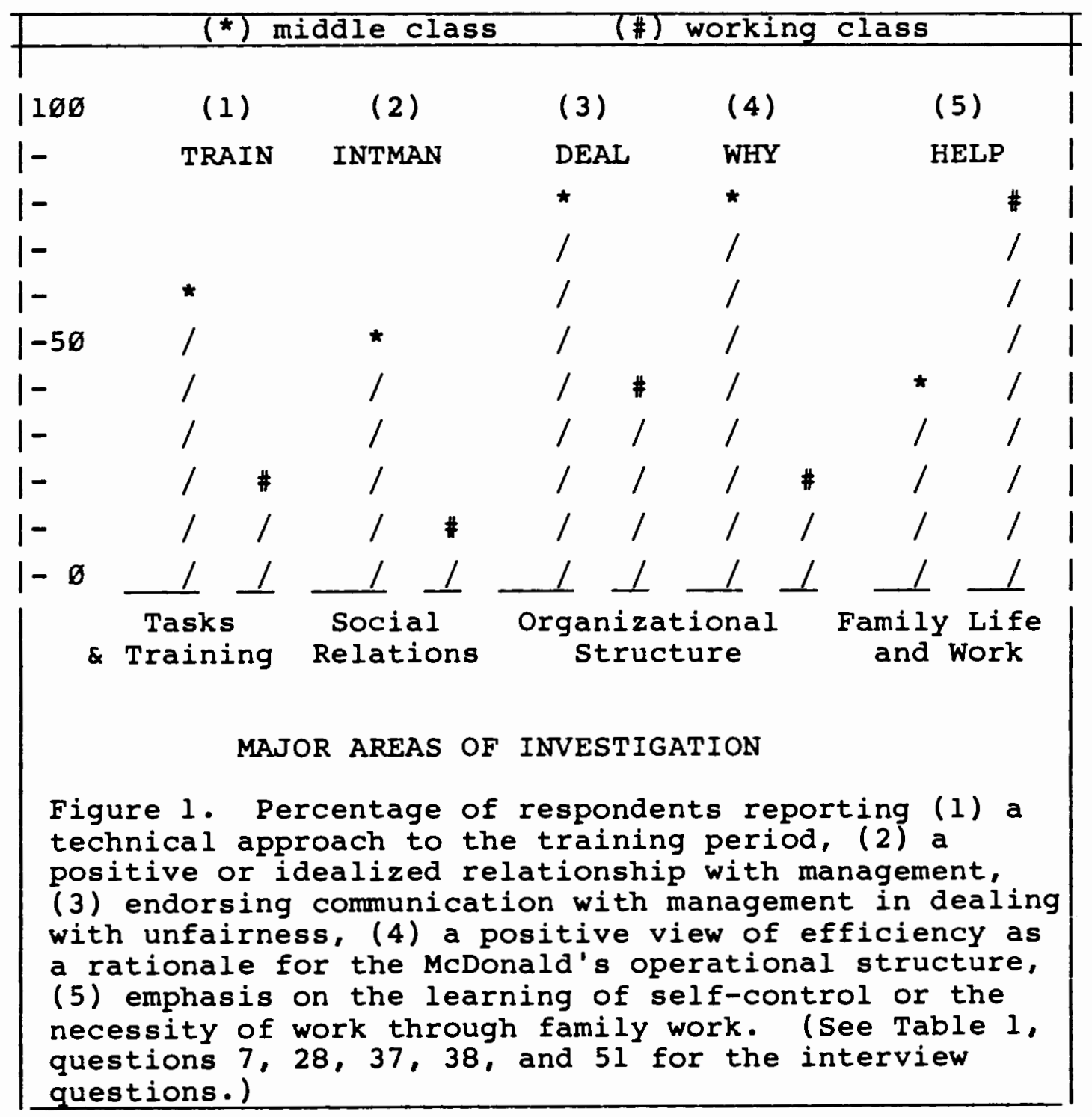




\section{FIGURE 2}

FINDINGS RELATED TO MOTIVATION FOR EMPLOYMENT

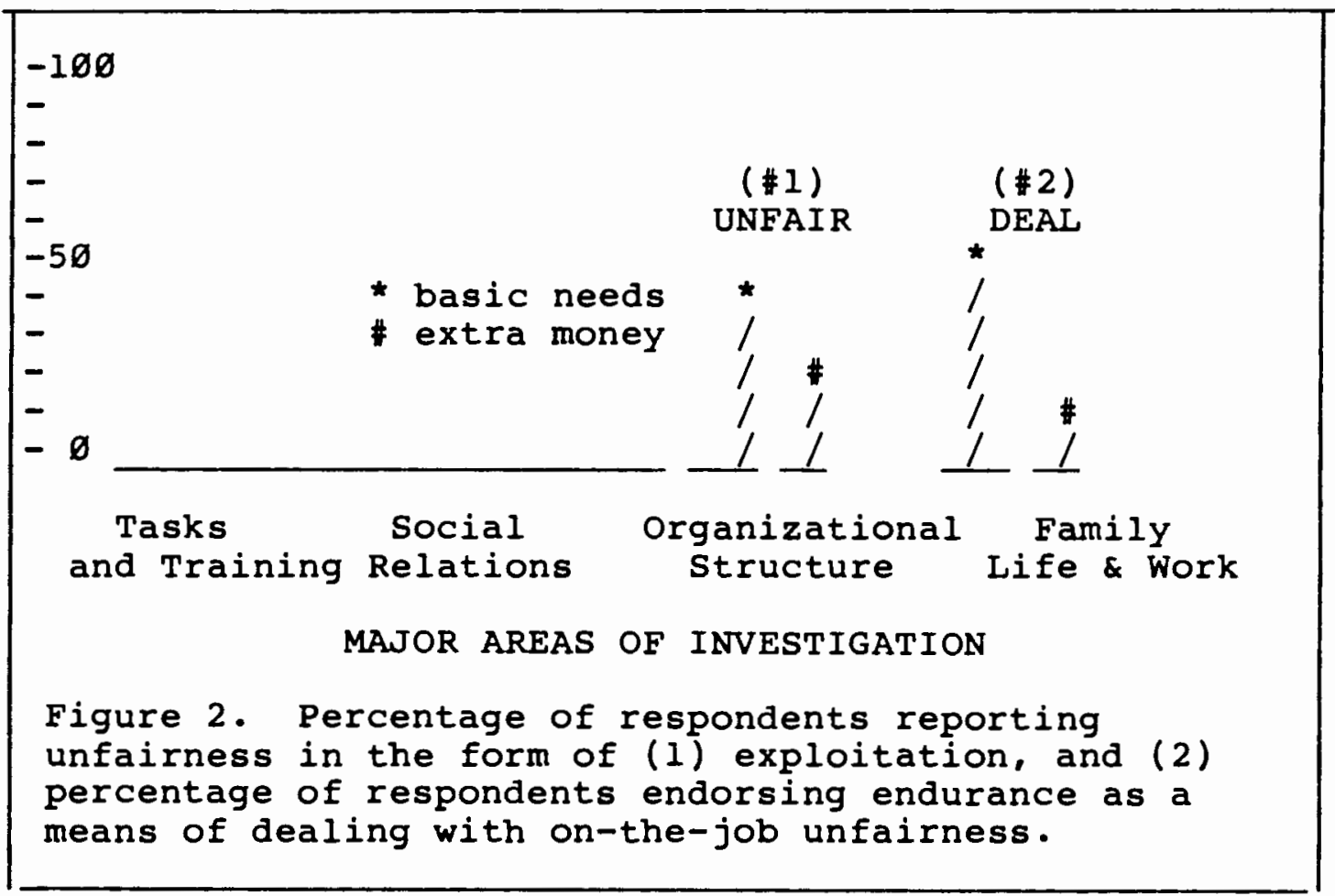

Tasks and Training

Several questions at the beginning of the interview schedule probed for the participants' retrospective accounts of experiences leading to work at McDonald's. A series of questions followed that focused on the respondents' experience of the training period and the 
nature of work tasks. The interest here was in assessing respondents' descriptions of their earliest memories of work. I focused initially on the entry period, reasoning that new reactions to the work would be most salient at this time, as would prior influences on conceptions of work. While questions about reliability of retrospective accounts have been raised (Robinson, 1976, p. 63), there is also evidence that individuals are able to accurately recall psychologically salient experiences, particularly those experiences which have meaning for self-concept and that mobilize affect (Tulving, 1972).

Middle Class respondents were more likely to adopt a technical approach to the training period. This finding may relate to class differences in the degree to which this kind of technological mastery is unique or challenging. Working class women may know many other women who run cash registers, take food orders, cook, etc. Having become more familiar with this kind of work, they may view the learning of the skills necessary to master the technical tasks with less enthusiasm and/or with less anxiety. Hence, working class women may focus on some other, possibly sociopolitical, factors affecting their security at work.

Social Relations with Management and Co-workers

This series of questions focused on social relational aspects of work, probing for differences in respondents' 
views of co-workers, managers, and store owners. Initial feelings about social organization were established here as well as an assessment of the kinds and quality of alliances formed through this kind of work. Here, class differences were expected to emerge in respondents' accounts of their cooperation with versus resistance to organizational hierarchy in the workplace.

Relations With Managers. While social class was not a significant predictor of relations with co-workers, class differences were related to female adolescents' relations with managers. The working class adolescents were more apt to maintain emotionally distant relationships with managers whereas middle class adolescents were more apt to seek positive affective ties with managers. Earlier, in the discussion of developmental factors associated with these results, I addressed claims that working class parents focus more on overt behavior and appeals to parental authority and that middle class parents more often focus on motivational factors and appeals to feelings in disciplining children. Results of the present study suggest that there is another side to these findings concerning childrearing practices. Perhaps working class children learn a two-sided lesson: one must develop a capacity for submitting to authority but one must also learn to resist authority. If one becomes emotionally 
here was to probe respondents' overall reactions to the work setting, both positive and negative, as well as to identify motivational issues related to the desire for change.

\section{Class Differences in Approaches to Resistance/}

Mechanisms for Change. Middle class workers were more likely to view management positively than were working class workers. The lower frequency of close relationships with managers among working class respondents is a finding with implications for understanding resistance. As stated earlier, it may be the case that working class adolescents learn a meaningful lesson about the risks of forming emotional ties with people in authority and for that reason are apt to express resistance in the workplace in the form of emotional distance from managers. Additional findings in the area of resistance and mechanisms for change in the workplace contribute to a broader understanding of the basis for this emotional distance.

Middle class adolescents were more likely to identify the positive aspects of efficiency as a primary rationale for McDonald's work structure than were working class respondents. Thus, further study of the relationship between attitudes toward management and perceived rationale for McDonald's system could shed light on the mechanisms used to effect change. Middle class workers may in addition to having a more positive, less threatening 
experience of authority, (see this discussion, Relations with Managers) draw on the positive aspects of efficiency, i.e., some inherent value of the structure of the workplace, when making decisions about approaching management emotionally. They may be more likely to approach management emotionally because management is perceived as safe, non-threatening AND because they believe that the company's principles are morally benign or positive.

In addition to holding positive attitudes toward management and viewing the organizational structure as inherently good, middle class respondents were more likely to emphasize the importance of communication with management in response to perceived unfairness than working class respondents. Working class respondents were more likely than middle class respondents to endorse endurance of perceived unfairness. A small number of respondents from both middle and working class groups endorsed developing an individual or group form of resistance.

One contribution to an understanding of results of this kind is offered by Kohn (1977) in his discussion of class differences in conformity. Kohn found in his research on class determinants of orientation to work that the working classes were seen as more likely to embrace conformity to prescribed order in society, "hold a more authoritarian view of what is acceptable behavior, and will 
more rigidly reject behavior that does not conform to the acceptable." Middle class workers, in contrast, are seen as more likely to be open-minded and self-directed in their judgments about social values and in their tolerance of nonconformity (Kohn, 1977, p. 141; Christie, 1954). This aspect of class divergence is seen as having its origins in child-rearing practice and is reinforced by workplace experience. The results of the present study could be seen as supportive of Kohn's position that respondents from middle class families extend self-direction into work by approaching management with perceived unfairness, i.e., boldly approaching management with a complaint rather than simply absorbing the problem. Respondents from working class backgrounds, in contrast, demonstrate an acceptance of the rules, i.e. adopting less powerful, more passive forms of resistance or stoic endurance.

There is another way of looking at Kohn's findings, however. One argument suggests that conformity in Kohn's argument is too narrowly defined. Kohn (1977) defines conformity in terms of focus. Self-direction, according to Kohn, focuses on internal standards for behavior; conformity on externally imposed rules. Self-direction implies a concern with internal dynamics--one's own and other people's. Conformity is defined by an allegiance to the dictates of authority and a sensitivity to one's 
peers. The present study raises questions about the meaning of "conformity."

If we look at the workplace as a setting heavily regulated by hierarchical channels for registering complaints, stoic endurance begins to take on the character of a self-regulated means of coping with workplace grievances. While the question of the respondent's underlying motives for enduring, i.e., a means of rebellion vs. maintaining and approval of the status quo were not examined, enduring working conditions cannot be necessarily equated with overall conformity. I suggest that conformity may be as much a characteristic of managerial work as among the working class. Likewise, self-direction may also abound in the working class group where rebellion may take the form of passive resistance (Bowles and Gintis, 1976). While the enduring of working conditions is a more passive stance than acting upon unfairness overtly, a distinction can be drawn between expressing a willingness to participate in maintaining the status quo versus feeling internally rebellious but nonetheless restrained by authority, e.g., management's prescribed rules. Stoic endurance can be seen in this light as an expression of resistance. The present study falls short of making a full assessment of respondent's understanding of conformity. Underlying motives were only weakly ascertained through, for example, Question 31. (See Table I) Thus, the 
assumption that "endurance" equals "conformity" in this study is premature as is the related assumption that the following of prescribed "chains of command" in reporting unfairness are antecedents of "self-direction" and "open-mindedness."

Motivations for Seeking Employment, Unfairness and Resistance. With regard to motivations for seeking employment found in this study, not surprisingly, there are differences in how female working adolescents view unfairness and how they deal with it once it is conceptualized. These differences appear to be partially rooted in the adolescent's financial dependency on the job. These adolescents working to meet subsistence needs were far more likely to identify concerns about being exploited in their work. Furthermore, they were more likely to endure the unfairness than were adolescent's working for "extra" money.

Greenberger and Steinberg (1982) report that fewer than ten percent of working teenagers contribute a substantial portion of their money earned at work to support their families. In contrast, the sample drawn here consisted of a relatively high percentage (4øq) of workers who were employed as a means of meeting subsistence needs. However, it should be noted that these results are based on the subjective experience of the respondent. Further, the 
lack of a significant relationship of job need to social class suggests that these findings relate more strongly to respondents' feeling the need to work than to the respondent's degree of privilege. It may be that the actual circumstances of their financial reliance on their jobs were inconsistent with their perceptions. However, I reasoned that their experience of the work was based largely on their experience of feeling motivated to work by financial "need" versus financial "interest."

The outcome of this area of the study might easily be explained by the obvious--that working to meet financial obligations in the form of subsistence is inherently a more precarious and limiting position than working for the purpose of "gaining work experience" of the world or "developing social skills." Subjectively, these restrictions might take the form of feeling less powerful, less in control and less willing to take risks (Garson, 1977; Nelkin and Brown, 1984). Thus, an adolescent working to meet subsistence needs would be far less likely to jeopardize her job by acting on perceived unfairness. The second finding in this area might be explained using a similar line of reasoning but with an additional factor determining the final outcome. I found that while adolescents working for subsistence needs were less likely to act on perceived unfairness at work they were more likely to view exploitation as the primary form of 
unfairness in their work. Adolescents working for "extra money" or for self-development on the other hand, focused on either unfairness originating in the interpersonal dynamics at work or they were non-critical of the work. While job security is the chief concern for adolescents working for basic needs and job security is increased by not challenging the "status quo," this is not incompatible with the view that the work is exploitive. The pressure to conform may be only skin deep in this situation where financial pressures guide the argument as it is in Kohn's (1977) discussion of social class variables. That is, it seems that motives for working may be deferentially predictive of worker orientation. Those adolescents working to meet basic needs may conform to prescribed rules of behavior while underlying ideas about equity are more rebellious.

\section{Age Correlates in Knowledge of the Organizational} Structure. Not surprisingly, older adolescents were more likely to have worked longer at McDonald's and were also more likely to report some knowledge of the organizational structure. Older respondents reported some ideas about how to climb the hierarchical ladder independent of their inclination to do so. Apparently, the work provides a means of gathering information about upward mobility. There was, however a large discrepancy in the reported 
means of moving up. Older workers were nearly evenly divided between viewing promotion as (a) largely out of their control and based on the likes and dislikes of the management, and (b) based on individual merit, an aspiration largely dependent on individual effort and motivation ( 428 and 558 , respectively)

\section{Family Life and Work}

Variables related to class were of primary interest in the study from the outset. Social class was conceptualized as a defining factor of family life and contributes to the interpretive framework of socialization into the workplace. Questions probing for class background were followed by questions related to the structure of work in the home as well as the consequences of noncompliance to work rules in the home. This allowed me to explore additional factors related to family life, which influenced particular responses to work.

\section{Class Differences in the Family Work-Related Values.}

In the area of family life, middle class adolescents were more likely to identify opportunities for learning self-development in their family work environment than were working class respondents. Working class girls valued learning about the necessity of maintaining some kind of gainful employment. They report a sense of primary 
financial dependency on gainful work that is not often present in the reports of middle class adolescents. This finding is most consistent with research which indicates that working class parents are more likely to value the obedience, neatness, and cleanliness whereas middle class parents value curiosity, happiness, consideration, and self-control (Duvall, 1946; Kohn, 1977, p. 21). Further, working class parents' values center on adherence to external prescriptions, middle class values on self-expression. My research indicates that these values, embedded in the conditions of the lives of people of different social strata, are carried over into the workplace and are a determining factor in the judgments made about work. Thus, working class workers emerging from homes in which obedience, etc. are emphasized report that these tools were helpful in mastering work tasks. Likewise middle class workers were more likely to identify the learning of skills conducive to self-development, e.g., consideration of others feelings, when judging the usefulness of family lifestyle in work adaptation. 


\section{CONCLUSIONS}

One aspect of the study which is important to address here is the question of the importance of present class position over that of the family of origin. Kohn found that present class position is substantially more important in determining values and orientation than are class origins (Kohn, 1977, p. 138). This has implications for the outcome of my study in some important ways. As stated above, Kohn found that his working class interviewees were more likely to judge jobs by their extrinsic aspects than were middle class workers. I found, as categories were identified through content analysis of responses to the questions about the training period, that respondents commented about specific intrinsic aspects of the work, e.g., hours of work per week, break time allotment. Substantially broader attention to the extrinsic aspects of the job lead to some speculation about the importance here of present class position. These respondents are all employed in working class jobs, e.g., working at McDonald's. Thus, extrinsic values are for them generally more salient (though not yet entirely assimilated among middle class respondents) than intrinsic values. One important aspect of the orientation period for middle class 
adolescent workers may be socialization into the working class. This revamping of values may not be an easy task, however. The tenacity of the values acquired through class origins is substantiated by the observation that despite the impact of present work conditions our middle class adolescents entering the work force maintained strong class distinctions as, for example, the finding on perceived closeness toward management illustrates (class $x$ intman). As Kohn's research suggests, class matters more in determining whether workers are forced to focus on the extrinsic than in determining whether they are free to focus on the intrinsic (Kohn, 1977).

I was not able to judge, of course, whether these same effects would be obtained with class comparisons of male adolescents or in a comparative study of other types of workers. The tendency for both our middle class and working class adolescents to emphasize cooperation in describing interactions with co-workers does suggest that gender effects may override social class effects in this area.

It may also be that the shared experience of fast-food work does promote a capacity for group solidarity, quasi-independently of family background, and that this would be true for males and females. However, this emphasis on cooperation and mutual support was also a more tenuous stance for our middle class adolescents. The findings presented here underscore the importance of 
attending more closely to social class as a determinant of social cognition in adolescence and as a mediator of intragender differences.

Although the data were consistent with one of my initial predictions, there were a number of surprising results. The first of my two initial hypotheses seems to be unfounded in the results of this study. Adolescents from working class families were expected to be more cooperative and adolescents from middle class families more competitive in their stances toward co-workers. This outcome disconfirms my first prediction. Other surprising findings include a striking lack of consistent social class differences in the adolescents' perception of their own importance vis a vis the management (see question 21, Table I) or in their rationale for the absence of unionization among workers in McDonald's franchises (See question 41 , Table I). It seems likely, in retrospect, that the absence of social class differences in some of the comparisons may be due to the fact that for most of the adolescents there are very clear barriers to upward mobility in the fast-food industry as a whole. This factor, built into the structure of the work may limit working class and middle class workers differentially. Also, most of the women interviewed were not considering a career at McDonald's. It is possible that this sample characteristic removed any need for the women of any class 
to be competitive with each other. That is, thinking in terms of the structure of the workplace I might have predicted no significant difference.

In terms of the exploratory predictors, job need (whyjob) and age, the lack of significant results suggest that, as one possibility, the sample was not sufficiently heterogeneous to produce differences. Most of the young women working at McDonald's are not working there because they really wanted to work in the fast-food industry. Their motives for seeking employment were as a group based on needing the extra money for something. In addition, the age range studied here was not wide (16 years to 19 years). Had the study focused on a more heterogeneous group in either or both of these considerations the outcome may have been more impressive.

A number of methodological obstacles common in field studies of this kind may have contributed to the lack of significant results. First, there was the problem of forming an interviewing alliance with the respondent. Opportunities for gaining the trust of the interviewee were limited to the initial on-site introduction, a subsequent telephone contact to arrange a time and place for the interview, and the interview itself. Despite care taken to convey a sense of the confidential nature of the interview, the obtrusiveness of a tape recorded interview, may have contributed to a less than frank relationship with me. 
Secondly, the interview was lengthy and may have become tiresome for the respondent toward the end of the interview. I was aware of my own fatigue both with regard to the length of each interview and to the duration of the entire study. Future studies of this kind will require more careful attention to these factors: weighing the benefits of the consistency of a single interviewer against the problem of interviewer fatigue, and the importance of interviewer rapport. 
REFERENCES

Aronowitz, S. False Promises: The Shaping of American Working class Consciousness. New York: McGraw-Hil1, 1973.

Babbie, E. Survey Research Methods. Belmont, Ca.: Wadsworth Publishing Co., 1973.

Bailyn, L., and Schein, E. H. Life/career Conditions as Indicators of Quality of Employment: In A.D. Biderman and T.F. Drury (Eds.), Measuring Work Quality for Social Reporting • Beverly Hills, Ca.: Sage, 1976.

Baken, D. Adolescence in America: From Idea to social Fact. In J. Kagan and R. Coles, (Eds.), Twelve to Sixteen: Early Adolescence, New York: Norton, 1972.

Bateman, R. The Effect of Work Experience on High School Students' Scholastic Achievement. Occupations, 1950. 41. 129-148.

Behn, W., Carnoy, M., Carter, M., Crain, J., \& Levin, H. M. School Is Bad; Work Is Worse. Schl. Rev., 1974, 83, 49-68.

Bernstein, B. Class, Codes and Control. London: Kegan, Inc., 1974 .

Bowles, S., and Gintis, H., schooling in Capitalist America: Education Reforms and the Contradictions of Economic Life. New York: Basic Books, Inc., 1976.

Bluestone, B., Friedman, B., Harrison, R., Lawrence, R., Schultze, C. Do We Need an Industrial Policy? Harper's, April, 1985 .

Braverman, H. Labor and Monopoly Capital: The Degradation of Work in the Twentieth Century. New York: Monthly Review Press, 1974.

Bucknam, R. The Impact of EBCE: An Evaluator's Viewpoint. Illinois Career Ed. Jour. 1976, 33: $32-37$. 
Bulkeley, H. W. A word to Parents. Philadelphia:

Presbyterian Board of Publication, 1958.

Christie, R. Authoritarianism Re-examined. In: Richard Christie and Marie Johoda (Eds.): Studies in the Scope and Method of "The Authoritarian personality. Glencoe, Il1.: The Free Press, 1954 .

Cloward, R. A., and Ohlin, L. Delinguency and Opportunity: A Theory of Delinquent Gangs. New York: Free Press, 1960.

Cockborn, C. Brothers: Male Dominance and Technological Change. Longwood: Pluto Press, 1983.

Demos, J. \& Demos, V.: Adolescence in Historical Perspective. Journal of Marriage and the Family. 1969 , 11: $632-\overline{638}$.

Demo, D. and Savin-Williams, R. Early Adolescent SelfEsteem as a Function of Social Class: Rosenberg and Perlin Revisited. Amer. Jour. of Sociology, 1983, 88, 763-774.

Dohrenwend, B . \& Dohrenwend, B., (Eds.): Stressful Life Events. New York: Wiley, 1974 .

Duvall, E. Conceptions of Parenthood. Am. Jour. of Soc. 1946,52 (Nov.), 193-263.

Edwards, R. Contested Terain. New York: Basic Books, 1974.

Elder, G. H., Jr. Children of the Great Depression. Chicago: University of Chicago Press, 1974 .

Ewen, S. Captains of Consciousness: Advertising and the Social Roots of Consumer Culture. New York: McGrawHill, 1976.

Garson, B. All the Livelong Day: The Meaning and Demeaning of Routine Work. New York: Penguin Books, 1977 .

Ginzberg, E. The Job Problem. Scientific American. 1977, 237. 43-51. 
Greenberger, E., Steinberg, L., \& Ruggiero, M.: A Job is a Job is a Job--Or Is It?: Behavioral Observations in the Adolescent Workplace. Work and Occupations. $1982,9,79-96$.

Greenberger, E., Steinberg, L., \& Vaux, A. Adolescents Who Work: Health and Behavioral Consequences of Job Stress. Developmental Psychology, 1981, 17, 691-703.

Greenberger, E., Steinberg, L., Vaux, A., \& Mc Auliffe, S. Adolescents Who Work: Effects of Part-Time Employment on Family and Peer Relations. Journal of Youth and Adolescence, 1986, 9, 189-202.

Hacker, S. Sex Stratification, Technology and Organization Change: A Longitudinal Case Study of AT\&T. In: Rachel Kahn-Hut, et. al.., (Eds.), 258-266, Women and Work, New York: Oxford University Press, $19 \overline{82}$.

Hall, G.S. Adolescence: Its Psychology and Its Relation To Physiology, Anthropology, Sociology, Sex, Crime, Religion, and Education. New York: Appleton, 1882.

Hamilton, R. Class and Politics in the United States. New York: Wiley, 1972 .

Hamilton, S.F., \& Crouter, A. Work and Growth: A Review of Research on the Impact of Work Experience on Adolescent Development. Journal of Youth and Adolescence, $1986,9,323-338$.

Hepworth, G. H., Rocks and Meals. Boston: American Unitarian Association, 1870.

Hirschi, T. Causes of Delinquency. Berkeley: University of California Press, 1969.

Hochschild, T. K. The Managed Heart. Berkeley: University of California Press, 1983.

Horney, K. New Ways in Psychoanalysis. New York: W.W. Norton \& CO., 1966 .

Johnston, L., Bachman, J., and O'Malley, P. Monitoring the Future: Questionnaire Responses From the Nation's High School Seniors. Ann Arbor, Mich.: Institute for Social Research, 1982).

Keniston, K. Youth and Dissent: The Rise of the New Opposition. New York: Harcourt, Brace, Javonovich, 1971. 
Kett, J. The History of Age Grouping in America. In: J.S. Coleman, et al.. (Eds.). Youth: Transition to Adulthood. Chicago: University of Chicago Press, 1974.

Kindel, S. Where's the Growth? Forbes, March 25, 1984.

Kohn, M. Class and Conformity (2nd ed.). Chicago: University of Chicago Press, 1977.

Kohn, M. and Schooler, C. Occupational Experience and Psychological Functioning: An Assessment of Reciprocal Effects. Amer. Soc. Rev., 1973, 38, 97-118.

Luxumberg, s. Roadside Empires. New York: Viking, 1985. Mortimer, J., and Lorence, J. Occupational Experience and Self-Concept: A Longitudinal study. Soc. Psych. Quar.. 1979, 42, 3ø7-323.

Nelkin, D., and Brown, M. Workers at Risk: Voices From the Workplace. Chicago: University of Chicago Press, 1984.

Nieva, V. Women and Work: A Psychological Perspective. New York: Praeger, 1981. Oppenheimer, M. White Collar Politics. New York: Monthly Review Press. 1985.

Oppenheimer, M. White Collar Politics. New York: Monthly Review Press, 1985 .

Parsons, T., and Bales, R. Family, Socialization and Interactive Process. Glencoe, Ill.: Free Press, 1955.

Pervin, L. A. Personality: Assessment, and Research. New York: Wiley \& Sons, 1980.

Piortkowski, C. S. Work and the Family system. New York: Free Press, $197 \overline{8}$.

Pleck, J. The Work-Family Role System. Soc. Prob., 1977, $\underline{24}(4), 417-427$.

Roddock, S. The Mammoth, Marvelous, Money Machine. Marketing and Media Decisions. 1982, Spring, 112-118.

Robinson, P. W. Fundamentals of Experimental Psychology: A Comparative Approach. Englewood Cliffs, N.J.: Prentice Hall, Inc., 1976. 
Rosenberg, M. and Perlin, L. Social Class and Self-Esteem Among Children and Adults. Am. Jour. of Soc.. 1978, 84, 53-77.

Rosenberg, M. Conceiving the Self. New York: Basic Books, 1979 .

Sacket, G. P. Observing Behavior. (Vol. 2.), Baltimore: University Park Press, 1978.

Shannon, L. Assessing the Relationship of Adult Criminal Careers To Juvenile Careers. (Microfiche No. NCJ 77744 , available from the National Juvenile Justice Clearinghouse of the National Criminal Justice Reference Service), United States Dept. of Justice Printing office, Washington, D.C., 1982 .

Steinberg, L. Jumping off The Work Experience Band Wagon. Journal of Youth and Adolescence, 1982a, 22, 183-205.

Steinberg, L., Greenberger, E., Garduque, L., Ruggiero, M., \& Vaux, A. The Effects of Working on Adolescent Development. Developmental Psychology, 1982c, 18, $385-395$.

Steinberg, L., Greenberger, E., Garduque, L. \& McAuliffe, S. High School Students in the Labor Force: Some Costs and Benefits of Schooling and Learning. Education Evaluations Policy Annual, 1982b, 4 , 363-372.

Steinberg, L., Greenberger, E., Jocobi, M. \& \& Garduque, L. Early Work Experience: A Partial Antidote For Adolescent Ego-Centrism. Journal of Youth and Adolescence, 1981b, 10, 14 1-157.

Steinberg, L. Adolescence. New York: Alfred A. Knopf, Inc., 1985 .

Steinberg, L., Greenberger, E., Vaux, A., and Ruggiero, M. Early Work Experience: Effects On Adolescent Socialization. Youth and Society, 1981a, 12(4), 403423.

Stevens-Long, J., \& Cobb, N. Adolescence and Early Adulthood. Palo Alto: Mayfield Publishing Co., 1983.

Straus, M., \& Holmberg, K. Part-Time Employment, Social Class, and Achievement in School. Soc. Social Res, 1968, 52, 224-230. 
Timpane, M.. Abramowitz, S., Bobrow, S. \& Pascal, A.

Youth Policy in Transition. Santa Monica, Ca.: Rand, 1976 .

Tulving, E. Episodic and Semantic Memory. In: E. Tulving $\&$ W. Donaldson (Eds.), Organization of Memory. New York: Academic Press, $1 \overline{972 .}$

Value Line Investment Survey, Edition 3, New York: Jan. 9, 1987 .

Vulcan, B. American Social Policy Toward Youth and Youth Unemployment. In M. Herman, S. Sadofsky, and B. Rosenberg (Eds.), Work, Youth, and Unemployment. New York: Thomas Y. Crowell, 1968.

Watkins, W., and Corder, R. Student Outcomes and

Participant Opinions in Experience-Based Career

Education Schools. unpublished Report, Berkeley:

Educational Testing Service, 1977.

White, K. R. Socio-Economic Status and Academic Achievement. Education: An International Review Series. $1980, \underline{4}, 79-81$.

Wishy, B. The Child and the Republic: The Dawn of Modern American Child Nurture. Philadelphia: University of Pennsylvania Press, 1969.

Wrigley, J. Compulsory School Laws: A Dilemma With a History. In J. Simon and D. Stipek (Eds.), Reconsidering Compulsory Schooling for Adolescents: Studies in Social Science, Education and Law. New York: Academic Press, 1968.

Yankelovich, D. Work, Values and the "New Breed." In C. Kerr and J. Rosow (Eds.), Work in America: The Decade Ahead. New York: Van Nostrand Reinhold, 1979.

Zajchowski, R. The Establishment Critics: A Summary of the Major Reports of Secondary Education in the 70's. Jour. of Exp. Ed., 1978, 1, 5-12.

Zaretsky, E. Capitalism, the Family, and Personal Life. New York: Harper and Row, 1976. 


\section{APPENDIX A}

INITIAL RESEARCH QUESTIONS

The following six research questions underlie the interview schedule. The primary aim throughout the study was to determine how teenage workers conceptualize their work experiences. The following questions served as a guideline for the formation of the final interview schedule.

1. What expectations do young people have for the work they are applying to do.

2. What are the worker's perceptions of the work they are supposed to do?

3. What are the workers' perceptions of what their managers do, including different levels of management.

4. What are the workers' perceptions of the intrinsic rewards of work?

5. What are the workers' perceptions of why work is structured in the way it is? Can they conceive of alternatives?

6. What values/attitudes acquired within the family contribute to responses to work discipline or forms of resistance? 


\section{APPENDIX B}

\section{CONSTENT FORM}

All participents were required to consent to be tape recorded. Participants under 18 were required to verify parental consent. The consent form is printed below.

Dear McDanald's emplojee,

We are asking for your participation in a study being conducted by Dr. Jan Hakken and a greduate student, Joyce Korschgen, from the Department of Psychology at Portland State University. This study will explore the experiences and concerns of teenagers who work in the fast-food industry. We are also interested in family experiences which influence regpanses to the workplace.

Your contribution to this study is of extreme value. Although people have written books and articles on teenage employment, very little attention has been given to how teengers understand and feel about their work experiences. Therefore, your participation will contribute to a new area of study.

Your participation in this study will involve being interviewed by Joyce Korschgen. The interview will be tape-recorded so we can accurately transcribe what jou say and will take approximately one howr. You may select a confortable place to be interviewed outaide of the work setting. In the interview you will be asked a series of questions about your work experiences within your family and at MaDanald's.

Of course, your participation in this study will be kept entirely confidential. Your name will not be tape recorded and this informed consent form will be kept separately from your interview. While you may not directly benefit from participation in this study, it has been our experience that interviess of this type can be rewarding for participents.

Thank you for your cooperation.

Sincerely,

Janice Haaken, Ph.D. Joyce Korschgen

Aluplojee

Signature

Parent (if under 16)

Signature 
APPENDIX C

CATEGORY DEFINITIONS OF RESPONSES WITH MINIMAL VARIANCE

Background

Q3: How did you choose McDonald's for work?

The most frequent response to this question indicated that the job search was based on the hiring frequency of the enterprise. Less frequently, respondents mentioned a perceived low level of skill required of the work, geographic mobility/proximity, or the flexibility of work hours.

Q4: At the time you applied, what choices did you have for work?

All indicated that they had few or no other choices for work.

Q6: At the time you applied, what did you expect it would be like working there?

Responses were generally mired among positive and negative expectations. Positive expectations included thinking they would get a lot of hours of work in per day, that the work would be fun, fast-paced. Negative expectations centered around the embarrassment of working in fast-food, that the work would be extremely difficult, boring, dangerous, and/or stressful.

Tasks and Training

Q8: Describe the order of tasks that you learned during the training period.

Responses to this question were grossly similar. The order of learning was always described (nearly verbatim) as follows. "First, I watched video tapes about the lot and lobby, then they put you out there (in the lobby) for the rest of the day. The next day you watch the video on fries, then counter, cash register." Girls are rarely trained initially for grill work.

Q10: What was your first assignment?

Responses to this question were quite invariant. Workers are trained initially to attend to cleaning the parking lot and lobby area. Many mentioned the feeling of isolation that they experienced during this period. 
APPENDIX C (continued)

Q12: What kinds of decisions can you make about the work?

Responses to this question indicated that all respondents searched for some means of control through decision-making at work. Decision-making efforts were described in several different ways. However, the theme of making decisions that would help reduce the stress of the work was nearly universal, i.e., managing emotional reactions to the pace, trying to stay calm. Not infrequently, this response was accompanied by references to technical control and/or resistance to managerial control, i.e., changing the order of tasks, timing oneself against another worker, setting up game strategies, slowing the pace, giving away extra sauce.

Mobility

Q14: How far up do jou want to move?

Results of this probe were as follows: 28 respondents reported no interest in moving up; 5 reported some interest, and 4 reported high interest in moving to a higher position at McDonald's.

Q16: Can you tell me anything you remember about your early feelings about the other employees?

Themes similar to those of question 15.

Social Organization

Q19: What do you know about how the company is set up and how this store relates to the corporation?

Most didn ${ }^{-} t$ know or give vague answers. Some discussion of corporate inspections and tight control by owner. Respondents of ten made reference to management's emphasis on petty details.

Q20: How do the owners influence what goes on in the store.

Most have vague impression of owner. He is the one that signs the checks. Aware of tension when owner comes around. Owner tends to demonstrate the mechanics of french fry preparation.

Q22: What differences are there between the in-store manager and the franchise supervisor?

Most did not know how to answer this question, who the franchise manager was, and/or that there were any differences other than divisions of power and authority. 
APPENDIX C (continued)

Q24: Can you tell me anything you remember about your early feelings about the franchise supervisor?

Most reported reluctance to approach the franchise supervisor or did not know who he was.

Q25: What is the store manager's job?

Mostly general descriptions of technical tasks and keeping order or helping out crew. Some reference to the freedom the manager has, e.g., "The higher up you go the less vork you do."

Q26: Do you think there is a need for a store manager?

All see managers as necessary but give different reasons and some express a degree of ambivalence. A few respondents felt that the store could be run by the workers alone. There was some criticism of the extensive layering of management, i.e., too many managers or too many levels of management.

Q29: How do they get people to do things?

Most frequently, respondents said that the managers "just tell you to do it--and then you do." This response was sometimes accompanied by references to some vague injustice or discomfort with subordination.

Q30: Are there incentives the company offers you to work harder?

Most identified "pay raises" as the typical incentive. Occasionelly a respondent would mention the "employee of the month" program, frequently with some degree of contempt for the program or embarrassment about having been a chosen "winner" of the award.

Resistance

Q33: What kinds of things do you do after work?

Responses varied according to the time at which the worker got off work. Workers who worked the late shift tried to relax and sleep while those who worked mornings or evenings did homework, prepared meals, or watched TV. Trying to relax was the most common theme.

Q34: Do employees have an organized way of talking about their concerns away from the managers? 
APPENDIX C (continued)

Most commonly, respondents refer to the "crew meetings" set up by and attended by management. This response does not really answer the question of whether employees are encouraged to have meetings away from management. My further occasional probes for information specifically about such worker organized meetings found little evidence of any sustained or consistent organization. So-called "crew meetings" were irregular, infrequent, and according to respondents nonproductive. The distribution of responses was as evenly split between those who said that meetings were theoretically part of the job but that during their employment no such meeting had taken place and those who said that there had been a meeting once or twice per year. No respondent indicated that the meetings were frequently or regularly scheduled.

Q36: Do you think the pay and benefits are fair?

The wage was characterized by 13 respondents as unfair and/or inadequate. Fourteen girls said that the wage was acceptable since they were young people not supporting a family, four respondents felt it was fair considering they had no plans to continue working in fast-food or considering they worked only a few hours. There were numerous references to the incongruity of working to a "maximum," i.e., to exhaustion, and being paid "minimum" wage. Occasionally, a respondent would include a reference to "pay raises" noting that the raises were also at a minimum (\$.05-.10/hr./increase.) Increases, they report, are wholly too infrequent and many feel the performance reviews are systematically delayed by management to avoid having to increase wages.

The reference to any employee benefits was met with curiosity by a few workers and laughter by others who wondered what I meant by employee "benefits." There are few employee benefits at McDonald's but the sole example given, if any, was the food allowance of $\$ .35$ to $.45 / \mathrm{hr}$. For every hour worked the employee is allowed this amount toward the purchase of McDonald's food, to be eaten on the premises. This benefit is not transferable or cumulative.

\section{Change}

Q40: How do you think a change like you just mentioned would happen?

Most respondents felt that fundamental changes were quite unlikely, e.g., larger working areas, pay increases "across the board." Changes of this nature would require something bordering on revolution, e.g., "we"d probably all have to threaten to quit or something." More minor changes such as cotton uniforms, different 
APPENDIX C (continued)

kinds of music, longer breaks, were approached through management but even these methods were generally seen as unpromising.

Q42: Do you think these kinds of jobs are good for teenagers?

All respondents answered affirmatively. Commonly, they referred to the usefulness of learning to get along with people, adjusting to the world of work, making new friends, learning to handle money. The discontinuity of responses to this question vs. responses to other questions measuring "satisfaction," e.g., question 35 (above), is noted. Apparently, for some of the respondents job satisfaction is unrelated to or inversely related to the overall benefits of teenage employment.

Q43: What do you think teenagers learn about authority in their work?

1. Focus of response on the realized authority of the management:

a: Power of the management position: Recognition that someone is in a powerful position, feels threatened and intimidated by authority. "They can fire you any time they feel like it." Management is non-benevolent. "You just have to learn to take orders."

b: Familiarity/benevolence of authority figures: Mentions to possibility of being frank with managers, open and friendly. "He's just my brother--I like him a lot." Being in a special position in the managers eyes. Sees managements position as respectable and attractive. May be critical of co-workers hostility toward management.

2. Focus on the realized authority in themselves:

a: Being in charge of the drawer, controlling the money. Views the job as an opportunity to induce authority in her "presentation to the public," or her ability to sell. Being in charge of the new people. Learning to control the use or misuse of authority.

b: Preparatory: Learns to be a responsible, hard worker. May mention being able to take another job easier than someone who has never worked. Learning to take criticism and rigid demands.

\section{Drug Use}

Q44: Do you think there is a greater use of drugs and alcohol among teenagers that work? 
APPENDIX C (continued)

Most teenagers indicated that there was little chance that drug use was a problem while teens were on the job. Most, in fact, qualified responses with the suggestion that the job required too much top speed energy to do "stoned" or drunk. Very few references vere made in the entirety of the interviews to substance abuse (other than nicotine). In the responses to question \#33, what do you do after work?, only one person indicated drug use or activity after work. Interestingly, there was a consensus of opinion on the increase of cigarette smoking among teenagers that work. All indicated that the chances of starting to smoke while working were substantially increased primarily due to the stress of the job.

Family Life

Q46: How do you think your parents feel about their jobs?

Responses here vere variable. Many felt their parents were quite satisfied, others that parents were quite unhappy with their work. There were few identifiable themes in the responses. One possible theme concerns the respondent's views of their mothers. Many have positive views of mothers capabilities. Sees mothers as having been deprived of opportunities or mothers having had to fight for their rights. Further questions about the respondent's interactions with their mothers might be useful.

Q47: What about the way you were raised influenced how you hande your job?

Responses invariably followed along the lines of learning to take orders or learning to manage time properly. References to learning to clean things well were noted.

Q48: What kinds of jobs or responsibilities did you have at home?

Most respondents had considerable responsibility for household tasks. There was a common mention of taking care of their brothers.

Q50: Is there anything you would change about the rules for work at $\operatorname{hom} \theta$ ?

Most report no significant change desired.

Q52: What do your parents want you to get out of the experience of working as a teenager?

The response to this question was consistent. Most respondents felt their parents wanted them to work in order to prepare themselves for future jobs. 
APPENDIX C (continued)

Q53: What do you imagine yourself doing when you are older?

Various responses either describing full time involvement in family life or working outside the home pert or full time.

Q54: In what ways do you see McDonald's preparing you to do that?

Most often respondents saw no preparation inherent in the work they were now doing other than learning to work with the public. There were no references to skilling of any kind.

Q55: What do your parents expect you' 11 be doing as an adult?

Consistently, "Whatever I want to do." Or "Whatever makes me happy." 
APPENDIX D

RESULTS OF RELIABILITY STUDY

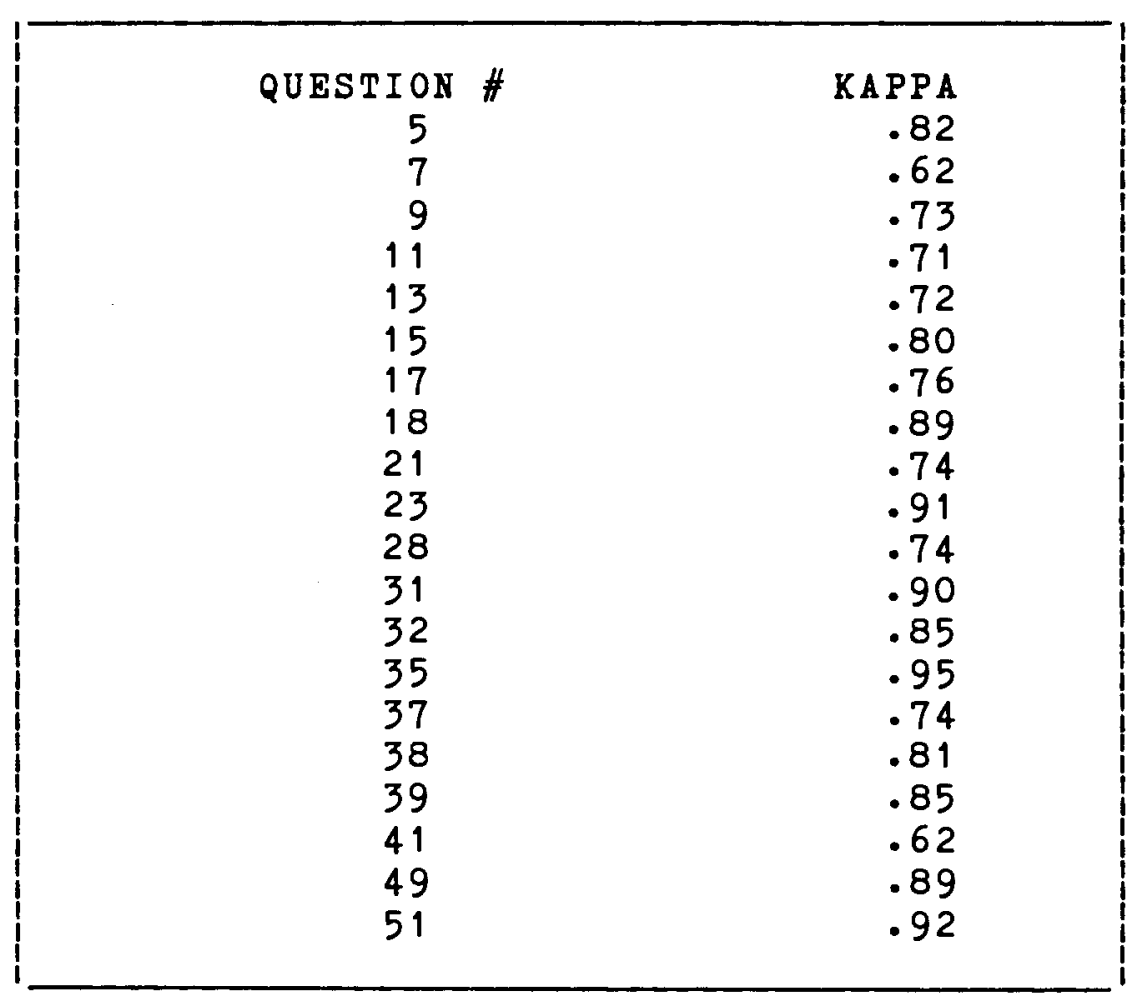

